\title{
Conceptualizing Tolerance as Recognition: Black American Endowed and Distinguished Professors of Education in US Colleges and Universities
}

\author{
Amadu Jacky Kaba \\ Seton Hall University, South Orange, NJ, USA \\ Email: kabaamad@shu.edu \\ Received 8 November 2015; accepted 10 January 2016; published 13 January 2016 \\ Copyright (C) 2016 by author and Scientific Research Publishing Inc. \\ This work is licensed under the Creative Commons Attribution International License (CC BY). \\ http://creativecommons.org/licenses/by/4.0/

(c) (i) Open Access

\begin{abstract}
This study analyzes a compiled list of Black American endowed and distinguished professors of education for the 2013-2014 academic year published by the Journal of Blacks in Higher Education. Conceptualizing tolerance as recognition, the study claims that there is a gradual increase in the appointments of Blacks to endowed or distinguished professorships in many different disciplines at colleges and universities in the United States. Among the findings are: of the 51 scholars, men accounted for the majority; the South and Midwest regions of the US employed a high majority of these scholars, and the majority of them also earned their terminal/highest degrees in those two regions; almost eight out of ten earned a Ph.D.; almost seven out of ten earned their terminal/ highest degrees in education; and almost half of them earned their terminal/highest degrees from the 1960s to the 1980s. Finally, the discussion section focuses on 1) an explanation of the gender gap among the 51 scholars; 2) the predominance of the South and Midwest regions 3) the relative underrepresentation of Ivy League institutions; and 4) the underrepresentation of Historically Black Colleges and Universities (HBCUs).
\end{abstract}

\section{Keywords}

Black Americans, Endowed Professors, Distinguished Professors, Education, Employment, Elite Institutions, Region, Gender

\section{Introduction}

Black Americans have made gradual progress in entering the ranks of the faculty of colleges and universities

How to cite this paper: Kaba, A. J. (2016). Conceptualizing Tolerance as Recognition: Black American Endowed and Distinguished Professors of Education in US Colleges and Universities. Sociology Mind, 6, 1-31. 
across the United States, especially in the post-1960s era. By 2011, of the 761,619 full-time instructional faculty in degree granting postsecondary institutions in the United States, Blacks accounted for 41,649 (5.5\%). In 2007, that figure was 37,930 . Within the professoriate, Blacks have also gradually earned tenure and promotion to associate and full professor positions. For example, by 2011, there were 6517 full professors and 8695 associate professors who were Black. In 2007, those figures were 5839 full professors and 7855 associate professors (“Table 315.20. Full-Time Instructional Faculty in Degree-Granting," 2014).

Apart from earning tenure and promotion to associate and full professor positions, another way professors are recognized is through appointments to endowed chairs or professorships or distinguished professorships. A number of interrelated factors can lead to one being recognized as an endowed or distinguished professor in the fields of education, the social sciences or other academic fields. Some of these factors include publications of a substantial number of scholarly journal articles in leading journals, publications of numerous books, being cited in other scholarly works or quoted in the media, being an excellent teacher, and mentoring graduate students especially leading to successful completion of doctoral work (Barbezat, 2006; Kaba, 2009, 2013a; Price, 2008).

It is noted that: "An endowed professorship is an honor bestowed by a university on a faculty member who has earned great respect in an academic discipline. It also serves as a magnet for talented young faculty members and residents who want to work with the honoree" ("Endowed Chairs and Endowed Professorships," 2014). It is also noted that: "In higher education endowed professorships are coveted, and rightfully so. Typically the highest honor a college or university can bestow upon faculty, endowed positions are reserved for eminent scholars whose work is believed to substantially advance a discipline or field of study. Professors who hold endowed positions are national and international thought-and-service leaders; hence, they are deserving of such distinguished titles” (Hartlep, 2014). Stone (2001) also writes of a chaired or endowed professorship as: “...unique because it is the one criterion that depends almost exclusively on one or a combination of five qualities- superiority of intellect, excellence of scholarship, productivity of research, inspirational teaching, and in some instances, the charisma of leadership" (p. 121).

A distinguished professorship is very similar to an endowed professorship and it usually includes an endowed professorship. "A Distinguished Professor is an exceptional scholar with an international reputation for scholarly and/or research excellence" ("What is a Distinguished Professor?" 2014). According to the University of Michigan: "The Distinguished University Professorships recognize exceptional scholarly and/or creative achievements, national and international reputation, superior teaching and mentoring, and an impressive record of service" ("Distinguished University Professorships," 2014).

Although there is no exact figure of the total number of endowed professors in the United States, it could be in the tens of thousands. The number of distinguished professors in the United States could also be in the thousands. For example, as of July 16, 2014, the University of California system has 1700 endowed chairs or professorships ("President Napolitano Announces Matching Fund," 2014). According to the State University of New York:"Since the program's inception in 1963, SUNY has appointed 994 faculty to distinguished ranks, as follows, including these most recent appointments: 337 Distinguished Professorships; 296 Distinguished Service Professorships; 356 Distinguished Teaching Professorships; and 5 Distinguished Librarian Professorships" ("SUNY Board of Trustees Appoints 19 Faculty to Distinguished Ranks," 2014).

Why produce such a study? What is the relevance of this current study? This study is relevant because of a number of important reasons. First, in a very racially, ethnically, culturally and religiously diverse society as the United States, Black Americans are among the groups with the least opportunities in many important walks of life, including among faculty in colleges and universities in the United States. Therefore knowing about the number of Black endowed and distinguished professors in academia, including in the field of education can help us to gauge how much the society has evolved in accepting Blacks not just as professors, but also recognized as endowed and distinguished professors. It illustrates the increase of tolerance in the society.

Indeed, the study by Stone (2001) found that the total number of Black American professors with endowed chairs increased from 102 in 1993 to 122 in 1997 to 129 in 2001. A careful examination of the list of 129 Black American professors with endowed chairs in 2001 showed that 12 (9.3\%) were in the field of education (pp. 121-125), even though a very high proportion of doctorates awarded to Blacks are in the field of education. For example, in 2009, of the 5566 doctorate degrees earned in education by US citizens and permanent residents, 14.5\% (807) were earned by Blacks. The 807 doctorates earned by Black citizens and permanent residents in 2009 is $36.3 \%$ of the 2221 total doctorate degrees earned by Black citizens and permanent residents in that year (Kaba, 2013b: pp. 72-73). 
Yet in just the past 100 years, one can point to prominent Black American professors with earned doctorates from highly ranked institutions, including Harvard University who were never recognized with an endowed or distinguished professorship. As Stokes (2001) points out: “... African Americans rarely have been appointed to these esteemed positions in higher education. Even black intellectual giants such as W.E.B. Du Bois and Charles Drew never held a chaired professorship. Nor did Alain Locke, America's first black Rhodes scholar. The fact that there are so few African Americans who hold such positions further documents the marginalization of blacks in higher education” (p. 121). Hartlep (2014) notes that of the 378 total active endowed chairs in education in colleges and universities in the United States in his study, Asians accounted for only 8 (2.1\%).

Another important reason for the production of this study is to use it to motivate and inspire young Black or minority students in undergraduate and graduate institutions and also young Black or minority faculty. Many times it helps for a young person who wants to achieve something to see individuals in her or his group who have achieved such an accomplishment (Franklin, 1990; Kaba, 2009: pp. 154-155). As Hartlep (2014) notes in his study of Asian Americans who hold endowed professorships in the field of education in colleges and universities in the United States: "As a hard-working male Asian-American Assistant Professor of Educational Foundations at Illinois State University who earned his Ph.D. at the University of Wisconsin-Milwaukee and who one day would like [to] compete at receiving an endowed faculty position...”

This study builds on the research of Hartlep and Theodosopoulos (2014) published in the Journal of Blacks in Higher Education on October 9, 2014, entitled: "African Americans Who Hold Endowed and Distinguished Professorships in education.” Hartlep and Theodosopoulos (2014) present a list of 51 Black endowed (42) and distinguished (nine) professors in the field of education, employed in colleges and universities in the United States in 2014, including their names, pictures, institution of employment, name of the endowed or distinguished professorship, type of terminal/highest degree, and institution where terminal/highest degree is earned.

This current study begins by presenting a conceptualization of tolerance as recognition, as it relates to appointing Black scholars to endowed and distinguished professorships in colleges and universities in the United States. Next, the methodology section is presented to explain how the data in the study were collected and computed. Next, the findings/results and analysis are presented. Finally, the study goes on to present a discussion section that focuses primarily on 1) an explanation of the gender gap among the 51 scholars; 2) the high representation of the South and Midwest regions of the United States as the regions of employment and termin$\mathrm{al} /$ highest degree attainment of these endowed and distinguished professors of education; 3 ) the relative underrepresentation of Ivy League institutions; and 4) the underrepresentation of Historically Black Colleges and Universities (HBCUs).

\section{Conceptualizing Tolerance as Recognition}

The word "Tolerance” has been conceptualized from many perspectives. It is a word with many meanings. For example, as Moore and Walker (2011) note, "Tolerance is a complex concept with many meanings and definitions” (p. 48). Lee (2010) points out that "The definition of tolerance is as diverse as humanity itself” (p. 2). Saulius (2013) claims that: "The notion of tolerance is used in various contexts; nevertheless, its meaning is short of clearance and distinctness” (p.49). A careful examination of a substantial number of scholarly works on tolerance shows a number of interrelated key words or terms utilized to define or explain this concept: grace; diversity; equality; freedom; acceptance; endurance; negative; positive; forbearance; civil liberties; empathy; autonomy; accomplishments; democracy; belonging; citizenship; open-mindedness; and reconciliation (Almond, 2010; Von Bergen et al., 2012; Furedi, 2012; Henshaw, 2014; Lee, 2010; Moore and Walker, 2011; Nieto, 1994; Saulius, 2013; Schirmer et al., 2012; Yovel, 1998). Examining tolerance from the perspective of grace, Yovel (1998) writes that: "Tolerance in the past (even in such Enlightenment writers as Locke, Voltaire, and Mendelssohn) had a patronizing character: it was seen not as a justified claim, a right based on some universal principle, but essentially as an act of grace” (p. 897; also see Nieto, 1994). Furedi (2012) explains tolerance from the perspective of rights: "The ideal of tolerance demands that we accept the right of people to live according to beliefs and opinions that are different, sometimes antithetical to ours... Tolerance affirms the freedom of conscience and individual autonomy... tolerance is also a social/cultural accomplishment. A tolerant society is one where tolerance as a cultural orientation discourages and restrains social intolerance” (p. 31). Lee (2010) presents this definition of tolerance based on citizenship, "People are tolerant to the extent that they are willing to grant the full rights of citizenship uniformly and without exception” (p. 2). 
According to Saulius (2013), from a political perspective tolerance: “...means to impose authority to social groups which are labelled as 'minorities' ... So-called 'minority' gain toleration in exchange of due respect to so-called 'majority', in exchange of their passiveness. In such contexts 'toleration' is a spurious coin. 'Majority' demonstrates good will and absolute power, 'minority', in turn, remains loyal and accepts 'inferior position'” (p. 51). According to Von Bergen et al. (2012), tolerance is "the ability to accept the values and beliefs of others," (p. 111). Von Bergen et al. (2012) continue by pointing out that: "Tolerance is said to be 'indispensable for any decent society — or at least for societies encompassing deeply divergent ways of life' ... characteristic of many Western cultures... Tolerance has been recognized today as an especially important characteristic in pluralist, multicultural communities seeking to be free of oppression, violence, indignities, and discrimination... Tolerance is considered essential and a highly desirable quality in US society ... and one of the few non-controversial values nowadays...” (pp. 111-112).

Von Bergen et al. (2012) present classical and neo-classical definitions of tolerance: "Classic tolerance derives from the term's Latin roots - tolerare or tolerantia - the first the verb meaning to endure, the second the noun denoting forbearance... The neo-classical definition of tolerance asks citizens to be open-minded and empathetic toward a virtually endless parade of differences; it asks them to work sympathetically to build institutional and cultural arrangements that will accommodate different ways of life” (pp. 112-113). Moore and Walker (2011) note that: "Tolerance includes willingness to extend civil liberties to groups whose political views one dislikes... Tolerance makes one rely less on stereotypes for judgments while broadening perspectives and maintaining harmony/unity” (p. 49). According to Almond (2010), “tolerance is good” (p. 131; also see Henshaw, 2014). Schirmer et al. (2012) point out that: "In most political and academic contexts, tolerance is considered as something positive. It is seen as a cornerstone of modern pluralist democracies that is necessary for the maintenance of good relations between people of different ethnicities, cultures and religions...” Schirmer et al. (2012) point to a scholar who "...calls ethnic tolerance a democratic principle and mentions it in the same breath as equality...” (pp. 1049-1050).

This brings us to the concept of tolerance as recognition or respect. Nieto (1994) presents this definition of tolerance as "...the capacity for or the practice of recognizing and respecting the beliefs or practices of others" (p. 9). According to Decker (2011): “... 'recognition' is a normative concept denoting the ascription of positive status to a group or an individual by (an) other(s). In its larger meaning, it carries the implication that when a group or an individual can justifiably expect such a positive status-ascription, its denial (misrecognition) is unjustified and unethical” (pp. 215-216). Writing about the experience of Black Americans, Chrisman (2013) notes that: “[W.E.B.]Du Bois'sown formulation of the Talented Tenth had as its social base a minuscule black petty bourgeoisie at the turn of the nineteenth century that found its aspirations of recognition and advancement in white America blunted by a brutal racism” (p. 65). Boaduo (2011) presents this quote pertaining to recognition:

"the demand for recognition... is given urgency by the supposed links between recognition and identity, where this latter term designates something like a person's understanding of who they are (...). The thesis is that our identity is partly shaped by recognition or its absence, often by the misrecognition of others, and so a person or group of people can suffer real damage, real distortion, if the people or society around them mirror back to them a confining or demeaning or contemptible picture of themselves. Nonrecognition or misrecognition can inflict harm, can be a form of oppression, imprisoning someone in a false, distorted, and reduced mode of being” (p. 356; also see Wagner, 2011).

Schirmer et al. (2012) present this explanation about minority groups, and that the word respect received:

“...its political significance for ethnic and racial relations through the social struggles of African Americans... 'the glue that binds people together'... as 'a moral building stone or even gatekeeper for a moral and humanitarian community'. These quotations emphasise the unifying and community-building perceptions of respect, marking a big contrast to the notion of tolerance which, as we have seen, rather divides majorities and minorities into a hierarchical relation of insiders and outsiders. Although a key ingredient of any social relation, respect becomes the most significant for marginalised individuals, individuals of lower status and individuals with habits and practices deviating from societal norms. Often, they are shown implicitly or explicitly that their presence is tolerated but not appreciated, that they were not asked to be there and now have to be 'coped with'. Respect becomes an issue for these individuals for the reason that they are deprived of it” (p. 1053; also see Thomas, 2010; Lawrence-Lightfoot, 1999). 
According to Boaduo (2014): "The issue of the equality of the races entails a definitive recognition of the equality of all social classes in every nation of the world" (p. 38).

The discussion of the concept of tolerance in this section plays a very important role in understating the positive recognition that Black American scholars are earning in colleges and universities in the United States. The fact that in 2001 there were only 129 Black endowed professors in the country, with only 12 in the field of education, but by 2014 there were 51 such scholars in the field of education alone, shows that the society is gradually becoming tolerant. Mondak and Sanders (2003) note that in measuring intolerance using a scale ranging from 0 - 15, with high scores representing intolerance, intolerance is declining in the United States, from 7.24 in 1977 to 5.28 in 1998 (27\% decline) (pp. 493-494; also see Kaba, 2008). According to Brace et al. (2002), from 1974 to $1998,60 \%$ of the people in the United States (excluding Hawaii, Idaho, Maine, Nebraska, Nevada and New Mexico) were tolerant (p. 176; also see Kaba, 2008).

This increase in tolerance is not just of people of color or Blacks as humans in general, but in academia in particular, the recognition of their ideas through their research and teaching. More importantly, one must also highlight the diversity of the institutions that are recognizing or showing respect for the research and ideas of these prominent scholars. Some of these endowed chairs and distinguished professorships are bestowed on these Black scholars by religious private institutions, secular private institutions, and by state institutions, which means in many instances, either the governor of the state or her or his representatives have to approve or sign the documents for the recognition to become official. It is in this context of tolerance as recognition that one must examine this study.

This does not mean that one is omitting the ongoing discrimination that Black Americans are experiencing, especially as one could point to many examples of how serious it is getting under the Barack Obama presidency. For example, Agiesta and Ross (2012) reported for the Associated Press that their poll showed that, “...51 percent of Americans now express explicit anti-black attitudes, compared with 48 percent in a similar 2008 survey" (also see Bobo et al. 2012; Samson \& Bobo, 2014; Kaba, 2012a: pp. 413-417). At Predominantly White Institutions, many times it seems as if Black faculty members are in a "Loin’s Den”. As Lemelle Jr. (2010) points out:

"Many in the black professoriate claim they experience terror on predominately-white college and university campuses... They have expressed the campuses are isolating where students and colleagues degrade and humiliate them... In addition, they say whites use networks they establish to exclude the black professoriate... The networks make it virtually impossible to maintain competitive research agendas. One consequence of this is black scholars in the professoriate are relegated to lower status groups in the academy and their college-and-university citizenship becomes of a different quality and quantity when it is compared to the experiences of the white professoriate (p. 106).

However, for this particular study the emphasis is to highlight this particular aspect of a positive development that includes racial tolerance. For example, of the 378 endowed professors of education in colleges and universities in the United States in the 2013-2014 academic year in Hartlep's (2014) study, the 51 Black scholars in this study accounted for 13.5 percent. Black Americans account for $13 \%$ of the American population.

The late Black American historian at Duke University, Dr. John Hope Franklin published an article in 1990 about his mentor the late Dr. W.E.B. Du Bois entitled: "W.E.B. Du Bois: A Personal Memoir," in which he discussed the need to point out some minor progress in explaining the Black experience in America. Specifically he writes that in 1956 Du Bois wrote an article entitled "Color-Line in the United States" and asked him to read it and offer any comments. Franklin notes that Du Bois, who he saw for the first time at age 11, when he went to give a speech in Franklin's home state of Oklahoma, was his role model and that he earned his doctorate in history in 1941 from Harvard University because he knew that Du Bois had earned his own doctorate in history at that same institution in 1895. By 1956, Franklin (1990) writes:

"I felt that our relationship by this time was truly collegial, and I responded with candor. I indicated that in his discussion of 'Courts and Police' it was dangerous to make sweeping generalizations. There were some towns even in the South that could not be described as places merely of 'tyranny and mob rule' and in some of them Afro-American jurors could be found. While the situation was 'as desperate' as he described it, I suggested some qualifying words such as 'largely' or 'mostly'. Churches, I added, were no longer one hundred percent segregated in the South, and I provided examples of interracial congregations. I concluded 
by saying that "the whole thing is a dark picture, and I fear that you have described most of it quite accurately” (pp. 421-422).

It is in this context that I want to highlight tolerance as recognition of the brain power of these scholars. In this context their research and ideas are "tolerated" by being recognized as endowed and distinguished scholars, just as the research and ideas of scholars from other racial groups are "tolerated” by being recognized when they are appointed to endowed and distinguished professorships.

\section{Methodology and Data Reliability}

In their compilation of Black endowed and distinguished professors of education in colleges and universities in the United States, Hartlep and Theodosopoulos (2014) list the names of all 51 professors, their pictures (excluding one male), name of the endowed or distinguished professorship, institution of employment, type of terminal/ highest degree earned, and institution where terminal/highest degree is earned. Table 1(a) and Table 1(b) (see appendix) present the names of the 51 professors broken down based on endowed and distinguished professorships as presented by Hartlep and Theodosopoulos (2014), name of endowed or distinguished professorship, institution of employment, type of terminal/highest degree earned, and institution where terminal/highest degree is earned. Table 1(a) and Table 1(b) show that of the 51 professors, 30 are men and 21 are women. Of the 42 endowed professors, 22 are men and 20 are women. Of the nine distinguished professors, eight are men and one is a woman.

I then created a primary table with the following variables: name, sex/gender, institution of employment, 2015 US News and World Report ranking of institution, state where institution of employment is located, region of the country where state is located (see appendix), institution where terminal/highest degree is earned, US News and World Report Ranking of institution, state and region of the country where terminal/highest degree is earned, year terminal/highest degree is earned, and academic field of terminal/highest degree. To find the year of graduation and the academic field or major of the terminal/highest degree earned, I searched the website of each scholar, their dissertations, and newspaper or magazine articles about them.

From this primary table, I created nine secondary tables of almost all of the variables mentioned above. I combined all 51 endowed and distinguished professors in the tables created, and because of the small sample size of the distinguished professors (nine), I decided to focus my study on all 51 of them as a group. As noted above, a distinguished professor usually also has an endowed chair. For example, one of the nine distinguished professors Dr. Chance W. Lewis of the University of North Carolina-Charlotte, presents this description of his title on one of his university websites: "Dr. Chance W. Lewis is the Carol Grotnes Belk Distinguished Full Professor and Endowed Chair of Urban Education at the University of North Carolina at Charlotte.”The aim here is to present an understanding of the institution of employment and terminal/highest degree attainment of these scholars to the general public.

\section{Findings/Results and Analysis}

\subsection{Institution of Employment of Black American Endowed and Distinguished Professors of Education}

The United States has a substantial proportion of the most elite colleges and universities in the world. For example, Kaba's (2012a) study of the top 200 universities in the world in 2009 shows that 54 (27\%) of them were located in the United States (p. 9). A substantial proportion of the scholars in this study are employed in those elite universities. Table 2 presents the institutions of employment of the 51 scholars in this study and the rank of each institution in the 2015 US News and World Report rankings.

All 51 scholars in this study were employed in 41 colleges and universities, all in the United States: the 30 men were employed by 27 institutions and the 21women were employed by 19 institutions. The University of Wisconsin-Madison employed 4 scholars (2 men and 2 women); 8 institutions employed 2 scholars each: Harvard University (2 women), Boston College (1 man and 1 woman), Ohio State University (2 men), University of California-Los Angeles (2 men), University of Chicago (1 man and 1 woman), University of Pennsylvania (1 man and 1 woman), and Vanderbilt University (1 man and 1 woman). The remaining 33 institutions employed one scholar each. 
Table 1. (a) Black American endowed and distinguished professors of education, by name, name of endowed or distinguished professorship, institution of employment, and sex (as of October 9, 2014); (b) Black American endowed and distinguished professors of education, by name, institution of terminal degree attainment, degree type, and sex (as of October 9 , 2014).

(a)

\begin{tabular}{|c|c|c|}
\hline Name & Name of Endowed/Distinguished Professorship & Institution of Employment \\
\hline \multicolumn{3}{|l|}{ Women } \\
\hline Norvella P. Carter & Endowed Chair in Urban Education & Texas A \& M University \\
\hline Beverly E. Cross & $\begin{array}{l}\text { Lillian and Morrie Moss Chair of } \\
\text { Excellence in Urban Education }\end{array}$ & University of Memphis \\
\hline Linda Darling-Hammond & Charles E. Ducommun Professor of Education & Stanford University \\
\hline Cynthia B. Dillard & Mary Frances Early Professor of Teacher Education & University of Georgia \\
\hline Vivian L. Gadsden & $\begin{array}{l}\text { William T. Carter Professor of Child } \\
\text { Development and Education }\end{array}$ & University of Pennsylvania \\
\hline Janet E. Helms & Augustus Long Professor in Measurement and Assessment & Boston College \\
\hline Joyce E. King & Benjamin E. Mays Endowed Chair & Georgia State University \\
\hline Gloria Ladson-Billings & Kellner Family Professorship in Urban Education & University of Wisconsin-Madison \\
\hline Sara Lawrence-Lightfoot & Emily Hargroves Fisher Professor of Education & Harvard University \\
\hline Carol D. Lee & Edwina S. Tarry Professor of Education and Social Policy & Northwestern University \\
\hline Veronica Evans Lewis & Kitty Degree Endowed Professorship in Education & University of Louisiana Monroe \\
\hline Bridget Terry Long & Saris Professor of Education and Economics & $\begin{array}{l}\text { Graduate School of Education, } \\
\text { Harvard University }\end{array}$ \\
\hline Alicia Moore & Cargill Professorship in Education & Southwestern University \\
\hline Velma McBride Murry & $\begin{array}{l}\text { Louis Autrey Betts Chair in Education and } \\
\text { Human Development }\end{array}$ & Vanderbilt University \\
\hline Carla O’Connor & Arthur F. Thurnau Professor & University of Michigan \\
\hline Margaret Beale Spencer & Marshall Field IV Professor of Urban Education & University of Chicago \\
\hline Gail L. Thompson & Wachovia-Wells Fargo Endowed Professor of Education & Fayetteville State University \\
\hline Vanessa Siddle Walker & Samuel Dobbs Professor of Educational Studies & Emory University \\
\hline Allyson L. Watson & $\begin{array}{l}\text { Eddings Endowed Chair for Urban Education, } \\
\text { Outreach and Research }\end{array}$ & Northeastern State University \\
\hline Maisha T. Winn & Susan J. Cellmer Chair in Teacher Education & University of Wisconsin-Madison \\
\hline \multicolumn{3}{|l|}{ Men } \\
\hline Walter Allen & Allan Murray Cartter Professor of Higher Education & University of California, Los Angeles \\
\hline James D. Anderson & $\begin{array}{l}\text { Edward William and Jane Marr Gutsgell } \\
\text { Professor of Education }\end{array}$ & University of Illinois-Champaign Urbana \\
\hline James A. Banks & $\begin{array}{l}\text { Kerry and Linda Killinger Endowed } \\
\text { Chair in Diversity Studies }\end{array}$ & University of Washington, Seattle \\
\hline Floyd D. Beachum & Bennett Professor of Urban School Leadership & Lehigh University \\
\hline Lynn Beckwith Jr. & $\begin{array}{l}\text { E. Desmond Lee Endowed Professorship in Urban Education } \\
\text { in Conjunction with the St. Louis Public Schools }\end{array}$ & University of Missouri-St. Louis \\
\hline
\end{tabular}




\section{Continued}

\begin{tabular}{|c|c|c|}
\hline Fred Bonner & Samuel DeWitt Proctor Endowed Chair in Education & Rutgers University \\
\hline Cory T. Brown & $\begin{array}{l}\text { Ashland Oil College of Education } \\
\text { Endowed Professorship }\end{array}$ & Murray State University \\
\hline Philip T.K Daniel & $\begin{array}{l}\text { William Ray and Marie Adamson Flesher Professor } \\
\text { of Educational Administration }\end{array}$ & The Ohio State University \\
\hline James Earl Davis & Bernard C. Watson Endowed Chair in Urban Education & Temple University \\
\hline Anderson J. Franklin & $\begin{array}{c}\text { Honorable David S. Nelson Professor of Psychology } \\
\text { and Education Director }\end{array}$ & Boston College \\
\hline Carl A. Grant & Hoefs-Bascom Professor of Education & University of Wisconsin-Madison \\
\hline Louis M. Gomez & $\begin{array}{l}\text { The John D. and Catherine T. MacArthur Foundation } \\
\text { Chair in Digital Media and Learning }\end{array}$ & University of California Los Angeles \\
\hline Preston C. Green III & John and Carla Klein Professor of Urban Education & University of Connecticut \\
\hline Jabari Mahiri & $\begin{array}{l}\text { William and Mary Jane Brinton Family } \\
\text { Chair in Urban Teaching }\end{array}$ & University of California, Berkeley \\
\hline H. Richard Milner IV & Helen Faison Chair in Urban Education & University of Pittsburgh \\
\hline Ernest Morrell & Macy Professor of Education & Teachers College, Columbia University \\
\hline Pedro A. Noguera & Peter L. Agnew Professor of Education & New York University \\
\hline Peter Sheppard & SLEMCO/BORSF Professorship in Education & University of Louisiana at Lafayette \\
\hline Howard Stevenson & Constance Clayton Professor of Urban Education & University of Pennsylvania \\
\hline William Lofton Turner & Betts Chair of Education and Human Development & Vanderbilt University/Peabody College \\
\hline Gregory J. Vincent & $\begin{array}{l}\text { W.K. Kellogg Professorship in Community } \\
\text { College Leadership }\end{array}$ & University of Texas at Austin \\
\hline John Yelding & Susan M. and Glenn G. Cherup Professorship in Education & Hope College \\
\hline
\end{tabular}

Women

Marilyn Strutchens

Mildred Cheshire Fraley Distinguished Professor

Auburn University

Men

Lamont A. Flowers

Howard L. Fuller

Jerlando F. L. Jackson

Chance W. Lewis

Kofi Lomotey

James L. Moore III

Charles Payne

William F. Tate
Distinguished Professor of Educational Leadership

Distinguished Professor of Education

Vilas Distinguished Professor of Higher Education

Carol Grotnes Belk Distinguished Professor of Urban Education

Chancellor John Bardo and Deborah Bardo Distinguished Professor of Educational Leadership

EHE Distinguished Professor of Urban Education

Frank P. Hixon Distinguished Service Professor

Edward Mallinckrodt Distinguished University Professor in Arts \& Sciences

\section{Clemson University}

Marquette University

University of Wisconsin-Madison

University of North Carolina-Charlotte

Western Carolina University

The Ohio State University

University of Chicago

Washington University in St. Louis

Source: Compiled and computed based on data from. Hartlep, Nicholas D., and Theodosopoulos, Kendra, 2014, October 9. "African Americans who Hold Endowed and Distinguished Professorships in Education,” Journal of Blacks in Higher Education. Retrieved from October 12 2014 and November 22, 2014 from: http://www.jbhe.com/2014/10/african-americans-who-hold-endowed-and-distinguished-professorships-in-education/. 
(b)

\begin{tabular}{|c|c|c|}
\hline Name & Terminal/Highest Degree & Institution \\
\hline \multicolumn{3}{|l|}{ Women } \\
\hline Norvella P. Carter & Ph.D. & Loyola University of Chicago \\
\hline Beverly E. Cross & Ph.D. & Ohio State University \\
\hline Linda Darling-Hammond & Ed.D. & Temple University \\
\hline Cynthia B. Dillard & Ph.D. & Washington State University \\
\hline Vivian L. Gadsden & Ed.D. & University of Michigan \\
\hline Janet E. Helms & Ph.D. & Iowa State University \\
\hline Joyce E. King & Ph.D. & Stanford University \\
\hline Gloria Ladson-Billings & Ph.D. & Stanford University \\
\hline Sara Lawrence-Lightfoot & Ed.D. & Harvard University \\
\hline Carol D. Lee & Ph.D. & University of Chicago \\
\hline Veronica Evans Lewis & Ph.D. & University of Southern Mississippi \\
\hline Bridget Terry Long & Ph.D. & Harvard University \\
\hline Alicia Moore & Ph.D. & University of Texas at Austin \\
\hline Velma McBride Murry & Ph.D. & University of Missouri \\
\hline Carla O’Connor & Ph.D. & University of Chicago \\
\hline Margaret Beale Spencer & Ph.D. & University of Chicago \\
\hline Gail L. Thompson & Ph.D. & Claremont Graduate University \\
\hline Vanessa Siddle Walker & Ed.D. & Harvard University \\
\hline Allyson L. Watson & Ph.D. & University of Oklahoma \\
\hline Maisha T. Winn & Ph.D. & University of California, Berkeley \\
\hline \multicolumn{3}{|l|}{ Men } \\
\hline Walter Allen & Ph.D. & University of Chicago \\
\hline James D. Anderson & Ph.D. & University of Illinois \\
\hline James A. Banks & Ph.D. & Michigan State University \\
\hline Floyd D. Beachum & Ed.D. & Bowling Green State University \\
\hline Lynn Beckwith Jr. & Ed.D. & Saint Louis University \\
\hline Fred Bonner & Ed.D. & University of Arkansas \\
\hline Cory T. Brown & Ph.D. & Ohio State University \\
\hline Philip T.K Daniel & Ed.D. & University of Illinois \\
\hline James Earl Davis & Ph.D. & Cornell University \\
\hline Anderson J. Franklin & Ph.D. & University of Oregon \\
\hline Carl A. Grant & Ph.D. & University of Wisconsin-Madison \\
\hline Louis M. Gomez & Ph.D. & University of California, Berkeley \\
\hline Preston C. Green III & Ed.D. & Teachers College/Columbia University \\
\hline
\end{tabular}




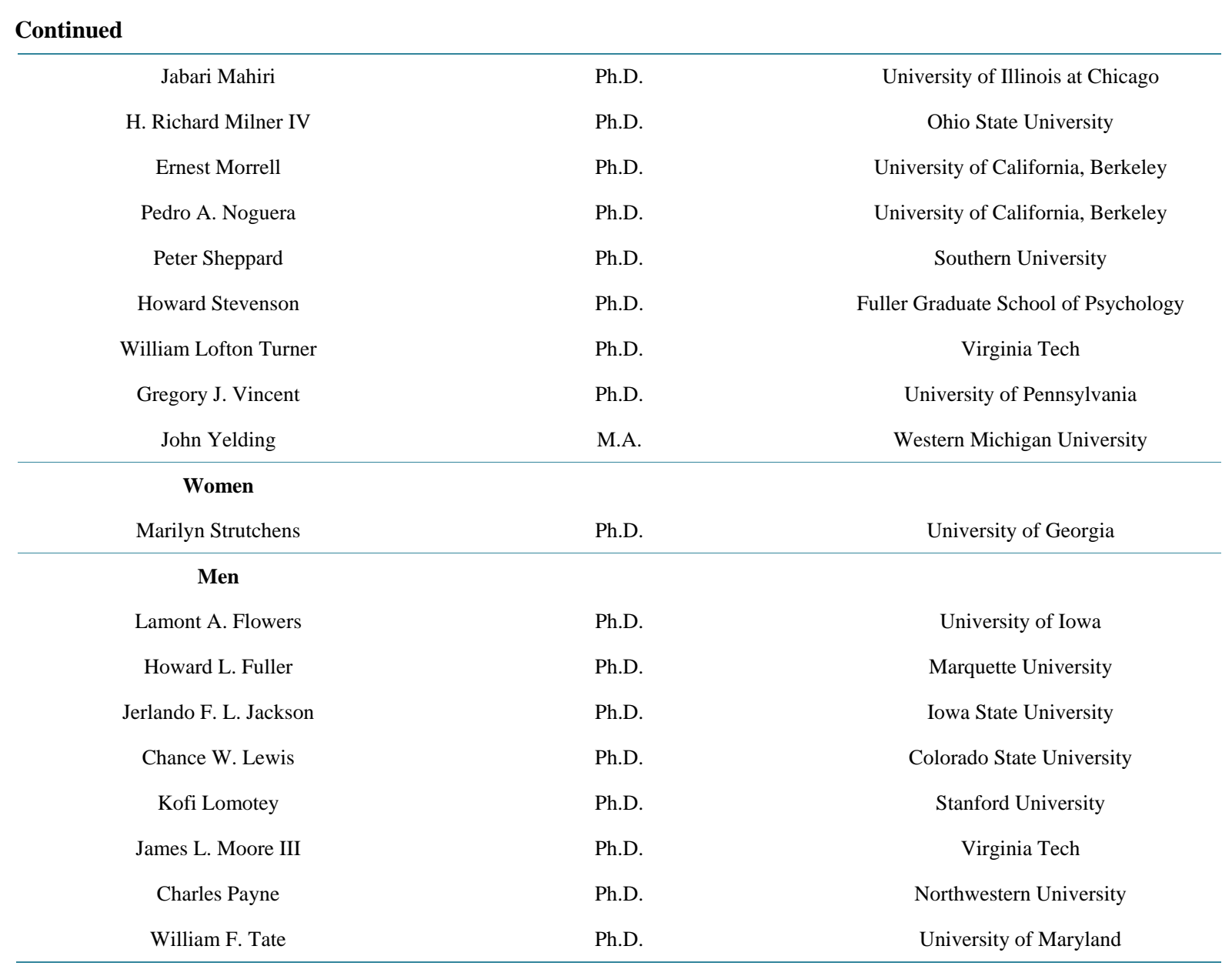

Of the 41 institutions, five are ranked in the top five among national universities in the 2015 US News and World Report rankings: Harvard University (\#2), Columbia University, Stanford University, and the University of Chicago (all tied at \#4), and the University of Pennsylvania (\#8). The following six institutions were included in the top 25: Northwestern University (\#13), Washington University of Saint Louis (\#14), Vanderbilt University (\#16), University of California-Berkeley (\#20), Emory University (\#21), and the University of California-Los Angeles (\#23). The following seven institutions were included in the top 48: Boston College (\#31), New York University (\#32), Lehigh University (\#40), University of Illinois-Urbana-Champaign (\#42), University of Wisconsin-Madison (\#47), and the University of Washington-Seattle (\#48) (Table 2; also see Hartlep, 2014; Kaba, 2009: pp. 163-164).

\subsection{US State of Employment of Black American Endowed and Distinguished Professors of Education}

As a nation, not only is the population of the United States the third largest in the world, but many of its 50 states are larger in number than many nations of the world. For example, if the state of California were a country, its 38.33 million population in 2013 would rank among the top 34 nations in the world (Algeria, ranked number 34 with 38.1 million people in 2013), and Texas, with 26.5 million people would rank among the top 47 nations (Yemen was ranked number 47 with 25.3 million people in 2013) ("Countries and Areas Ranked by Population: 2013," 2014). This means that among the 50 states and Washington DC there is competition for talent among colleges and universities and among businesses and other entities including state governments. It is therefore important to share with the general public the states where these prominent scholars are employed.

According to Table 3, all 51 scholars are employed in 21 states. There are five (9.8\%) scholars each employed in the states of Wisconsin ( 3 men and 2 women) and Pennsylvania (4 men and 1 woman); there were 
Table 2. Institution of employment of Black American endowed and distinguished professors of education, by sex, 20132014 academic year, and 2015 US News and World Report rankings.

\begin{tabular}{|c|c|c|c|c|}
\hline \multicolumn{5}{|l|}{$\mathrm{N}=41$} \\
\hline Institution of Employment & Men & Women & Total & 2015 US News \& World Report Rankings \\
\hline University of Wisconsin-Madison & 2 & 2 & 4 & 47 \\
\hline Harvard University & 0 & 2 & 2 & 2 \\
\hline Boston College & 1 & 1 & 2 & 31 \\
\hline Ohio State University & 2 & 0 & 2 & 54 \\
\hline University of California-Los Angeles & 2 & 0 & 2 & 23 \\
\hline University of Chicago & 1 & 1 & 2 & 4 \\
\hline University of Pennsylvania & 1 & 1 & 2 & 8 \\
\hline Vanderbilt University & 1 & 1 & 2 & 16 \\
\hline Auburn University & 0 & 1 & 1 & 103 \\
\hline Clemson University & 1 & 0 & 1 & 62 \\
\hline Emory University & 0 & 1 & 1 & 21 \\
\hline Fayetteville State University & 0 & 1 & 1 & Tier Two Regional Universities (South) \\
\hline Georgia State University & 0 & 1 & 1 & Tier Two (Best National Universities) \\
\hline Hope College & 1 & 0 & 1 & \#99 National Liberal Arts Colleges \\
\hline Lehigh University & 1 & 0 & 1 & 40 \\
\hline Marquette University & 1 & 0 & 1 & 76 \\
\hline Murray State University & 1 & 0 & 1 & \#26 Regional Universities (South) \\
\hline New York University & 1 & 0 & 1 & 32 \\
\hline Northeastern State University & 0 & 1 & 1 & \#84 Regional Universities (West) \\
\hline Northwestern University & 0 & 1 & 1 & 13 \\
\hline Rutgers University-New Brunswick & 1 & 0 & 1 & 70 \\
\hline Southwestern University & 0 & 1 & 1 & \#87 National Liberal Arts Colleges \\
\hline Stanford University & 0 & 1 & 1 & 4 \\
\hline Teachers College/Columbia University & 1 & 0 & 1 & 4 \\
\hline Temple University & 1 & 0 & 1 & 121 \\
\hline Texas A \& M University-College Station & 0 & 1 & 1 & 68 \\
\hline University of California-Berkeley & 1 & 0 & 1 & 20 \\
\hline University of Connecticut-Storrs & 1 & 0 & 1 & 58 \\
\hline University of Georgia-Athens & 0 & 1 & 1 & 62 \\
\hline University of Illinois-Urbana-Champaign & 1 & 0 & 1 & 42 \\
\hline University of Louisiana-Lafayette & 1 & 0 & 1 & Tier Two (Best National Universities) \\
\hline University of Louisiana-Monroe & 0 & 1 & 1 & \#81 Regional Universities (South) \\
\hline University of Memphis & 0 & 1 & 1 & Tier Two (Best National Universities) \\
\hline University of Michigan-Ann Arbor & 0 & 1 & 1 & 29 \\
\hline University of Missouri-Saint Louis & 1 & 0 & 1 & Tier Two (Best National Universities) \\
\hline
\end{tabular}




\section{Continued}

$\begin{array}{ccccc}\text { University of North Carolina-Charlotte } & 1 & 0 & 1 & 201 \\ \text { University of Pittsburgh } & 1 & 0 & 1 & 62 \\ \text { University of Texas-Austin } & 1 & 0 & 1 & 48 \\ \text { University of Washington-Seattle } & 1 & 0 & 1 & 14 \\ \text { Washington University in Saint Louis } & 1 & 0 & 1 & \text { \#37 Regional Universities (South) } \\ \text { Western Carolina University } & 1 & 0 & 51 & \end{array}$

Source: Compiled and computed based on data from: Hartlep, Nicholas D., and Theodosopoulos, Kendra, 2014, October 9. “African Americans who Hold Endowed and Distinguished Professorships in Education,” Journal of Blacks in Higher Education. Retrieved from October 12 2014 and November 22, 2014 from: http://www.jbhe.com/2014/10/african-americans-who-hold-endowed-and-distinguished-professorships-in-education/; "Best National Universities,” 2014, September. US News and World Report Rankings, Best Colleges, 15 ${ }^{\text {th }}$ Edition. Pages 66-180. Also see web site at: http://colleges.usnews.rankingsandreviews.com/best-colleges.

Table 3. US state of employment of Black American endowed and distinguished professors of education, by sex, 20132014 academic year.

\begin{tabular}{|c|c|c|c|c|}
\hline $\mathrm{N}=21$ & & & & \\
\hline State of Employment & Men & Women & Total & $\%$ \\
\hline Wisconsin & 3 & 2 & 5 & 9.8 \\
\hline Pennsylvania & 4 & 1 & 5 & 9.8 \\
\hline California & 3 & 1 & 4 & 7.8 \\
\hline Illinois & 2 & 2 & 4 & 7.8 \\
\hline Massachusetts & 1 & 3 & 4 & 7.8 \\
\hline Georgia & 0 & 3 & 3 & 5.9 \\
\hline North Carolina & 2 & 1 & 3 & 5.9 \\
\hline Texas & 1 & 2 & 3 & 5.9 \\
\hline Tennessee & 1 & 2 & 3 & 5.9 \\
\hline Louisiana & 1 & 1 & 2 & 3.9 \\
\hline Michigan & 1 & 1 & 2 & 3.9 \\
\hline Missouri & 2 & 0 & 2 & 3.9 \\
\hline New York & 2 & 0 & 2 & 3.9 \\
\hline Ohio & 2 & 0 & 2 & 3.9 \\
\hline Alabama & 0 & 1 & 1 & 1.96 \\
\hline Connecticut & 1 & 0 & 1 & 1.96 \\
\hline Kentucky & 1 & 0 & 1 & 1.96 \\
\hline New Jersey & 1 & 0 & 1 & 1.96 \\
\hline Oklahoma & 0 & 1 & 1 & 1.96 \\
\hline South Carolina & 1 & 0 & 1 & 1.96 \\
\hline Washington & 1 & 0 & 1 & 1.96 \\
\hline Total & 30 & 21 & 51 & 99.82 \\
\hline
\end{tabular}

Source: Compiled and computed based on data from: Hartlep, Nicholas D., and Theodosopoulos, Kendra, 2014, October 9. “African Americans who Hold Endowed and Distinguished Professorships in Education,” Journal of Blacks in Higher Education. Retrieved from October 12 2014 and November 22, 2014 from: http://www.jbhe.com/2014/10/african-americans-who-hold-endowed-and-distinguished-professorships-in-education/. 
four (7.8\%) scholars each employed in California (3 men and 1 woman), Illinois (2 men and 2 women), and Massachusetts (3 women and 1 man). There are three (5.9\%) scholars each employed in Georgia (3 women), North Carolina ( 2 men and 1 woman), Texas ( 2 women and 1 man), and Tennessee ( 2 women and 1 man). There are two (3.9\%) scholars each employed in Louisiana (1 man and 1 woman), Michigan (1 man and 1 woman), Missouri (2 men), New York (2 men), and Ohio (2 men). Finally, one (1.96\%) scholar each is employed in Alabama (a woman), Connecticut (a man), Kentucky (a man), New Jersey (a man), Oklahoma (a woman), South Carolina (a man), and Washington (a man) (Table 3; also see Kaba, 2009: p. 166).

\subsection{US Regions of Employment of Black American Endowed and Distinguished Professors of Education}

Geographically, the United States is a vast territory and one of the largest countries in the world, with an area of 9,826,675 sq km (50 states plus Washington, DC.): 9,161,966 sq km of land and 664,709 sq km of water. For comparative purposes, the United States is ranked third, behind Russia $(17,098,242$, sq km), ranked number 1 in the world; and Canada $(9,984,670 \mathrm{sq} \mathrm{km})$, ranked number 2 in the world. This means that with a population of 319 million in July 2014, ranked third in the world behind China (1.36 billion) and India (1.24 billion), there are many important differences (such as poverty rates, educational attainment rates, household income, health status, etc.) among the four official regions of the United States (Northeast, Midwest, South and West). Therefore, it is important to observe the breakdown of the regions where these prominent scholars are employed.

Table 4 shows the regions where Black endowed and distinguished professors of education were employed during the 2013-2014 academic year. According to Table 4, the South and the Midwest regions employed a very high majority of these scholars. Of the 51 scholars, 18 (35.3\%) were employed by institutions in the South; 15 (29.4\%) were employed in the Midwest; 13 (25.5\%) were employed in the Northeast; and five (9.8\%) were employed in the West.

Among the 30 male scholars, 10 (33.3\% of all men, but19.6\% of all 51 total scholars) were employed by institutions in the Midwest; nine (30\% of men, but $17.6 \%$ of total) were employed in the Northeast; seven (23.3\% of men, but $13.7 \%$ of total) were employed in the South; and four ( $13.3 \%$ of men, but $7.8 \%$ of total) were employed in the West.

Among the 21 female scholars, 11 (52.4\% of all women, but $21.6 \%$ of 51 total scholars) were employed by institutions in the South; five (23.8\% of women, but $9.8 \%$ of total) were employed in the Midwest; four (19.1\% of women, but $7.8 \%$ of total) were employed in the Northeast; and one ( $4.8 \%$ of women, but $1.96 \%$ of total) was employed in the West (Table 4).

\subsection{Institutions of Terminal/Highest Degree Attainment by Black American Endowed and Distinguished Professors of Education}

Table 5 presents the institutions where Black endowed and distinguished professors of education earned their terminal/highest degrees, and the 2015 US News and World Report rankings of those institutions. Just like their institutions of employment, a substantial number of the 51 scholars in this study earned their terminal/highest degrees at America's elite universities. All 51 scholars earned their terminal/highest degrees from 36 institutions,

Table 4. US region of employment of Black American endowed and distinguished professors of education, by sex, 20132014 academic year.

\begin{tabular}{|c|c|c|c|c|c|c|c|c|}
\hline Region of Employment & Men & $\%$ of Men & \% of Total & Women & $\%$ of Women & $\%$ of Total & Total & $\%$ \\
\hline Northeast & 9 & 30 & 17.6 & 4 & 19.1 & 7.8 & 13 & 25.5 \\
\hline Midwest & 10 & 33.3 & 19.6 & 5 & 23.8 & 9.8 & 15 & 29.4 \\
\hline South & 7 & 23.3 & 13.7 & 11 & 52.4 & 21.6 & 18 & 35.3 \\
\hline West & 4 & 13.3 & 7.8 & 1 & 4.8 & 1.96 & 5 & 9.8 \\
\hline Total & 30 & 99.9 & 58.7 & 21 & 100.1 & 41.16 & 51 & 100 \\
\hline
\end{tabular}

Source: Compiled and computed based on data from: Hartlep, Nicholas D., and Theodosopoulos, Kendra, 2014, October 9. “African Americans who Hold Endowed and Distinguished Professorships in Education,” Journal of Blacks in Higher Education. Retrieved from October 12 2014 and November 22, 2014 from: http://www.jbhe.com/2014/10/african-americans-who-hold-endowed-and-distinguished-professorships-in-education/. 
Table 5. Institutions where Black American endowed and distinguished professors of education attain their terminal/highest degrees, by sex, 2013-2014 academic year, and 2015 US News and World Report Rankings.

\begin{tabular}{|c|c|c|c|c|}
\hline$N=36$ & & & & \\
\hline Institution of Terminal/Highest Degree & Men & Women & Total & 2015 US News Ranking \\
\hline University of California-Berkeley & 3 & 1 & 4 & 20 \\
\hline University of Chicago & 1 & 3 & 4 & 4 \\
\hline Harvard University & 0 & 3 & 3 & 2 \\
\hline Ohio State University & 2 & 1 & 3 & 54 \\
\hline Stanford University & 1 & 2 & 3 & 4 \\
\hline Iowa State University & 1 & 1 & 2 & 106 \\
\hline University of Illinois-Urbana-Champaign & 2 & 0 & 2 & 42 \\
\hline Virginia Tech & 2 & 0 & 2 & 71 \\
\hline Claremont Graduate University & 0 & 1 & 1 & \#126 Best Education Schools \\
\hline Bowling Green State University & 1 & 0 & 1 & 173 \\
\hline Colorado State University-Fort Collins & 1 & 0 & 1 & 121 \\
\hline Cornell University & 1 & 0 & 1 & 15 \\
\hline Fuller Graduate School of Psychology & 1 & 0 & 1 & \#214 Graduate School Rankings in Psychology \\
\hline Loyola University of Chicago & 0 & 1 & 1 & 106 \\
\hline Marquette University & 1 & 0 & 1 & 76 \\
\hline Michigan State University & 1 & 0 & 1 & 85 \\
\hline Northwestern University & 1 & 0 & 1 & 13 \\
\hline Saint Louis University & 1 & 0 & 1 & 99 \\
\hline Teachers College/Columbia University & 1 & 0 & 1 & 4 \\
\hline Southern University-Baton Rouge & 1 & 0 & 1 & RNP Regional Universities (South) \\
\hline Temple University & 0 & 1 & 1 & 121 \\
\hline University of Arkansas-Fayetteville & 1 & 0 & 1 & 135 \\
\hline University of Illinois-Chicago & 1 & 0 & 1 & 149 \\
\hline University of Georgia-Athens & 0 & 1 & 1 & 62 \\
\hline University of Iowa-Iowa City & 1 & 0 & 1 & 71 \\
\hline University of Maryland-College Park & 1 & 0 & 1 & 62 \\
\hline University of Michigan-Ann Arbor & 0 & 1 & 1 & 29 \\
\hline University of Oregon-Eugene & 1 & 0 & 1 & 106 \\
\hline University of Oklahoma & 0 & 1 & 1 & 106 \\
\hline University of Pennsylvania & 1 & 0 & 1 & 8 \\
\hline University of Southern Mississippi & 0 & 1 & 1 & Tier Two (Best National Universities) \\
\hline University of Missouri-Saint Louis & 0 & 1 & 1 & Tier Two (Best National Universities) \\
\hline
\end{tabular}


Continued

$\begin{array}{ccccc}\text { University of Texas-Austin } & 0 & 1 & 1 & 53 \\ \text { University of Wisconsin-Madison } & 1 & 0 & 1 & 47 \\ \text { Washington State University-Pullman } & 0 & 1 & 1 & 138 \\ \text { Western Michigan University } & 1 & 0 & 1 & 173 \\ \text { Total } & 30 & 21 & 51 & \end{array}$

Source: Compiled and computed based on data from: Hartlep, Nicholas D., and Theodosopoulos, Kendra, 2014, October 9. “African Americans who Hold Endowed and Distinguished Professorships in Education,” Journal of Blacks in Higher Education. Retrieved from October 12 2014 and November 22, 2014 from: http://www.jbhe.com/2014/10/african-americans-who-hold-endowed-and-distinguished-professorships-in-education/; "Best National Universities," 2014, September. US News and World Report Rankings, Best Colleges, 15 ${ }^{\text {th }}$ Edition. Pages 66-180. Also see web site at: http://colleges.usnews.rankingsandreviews.com/best-colleges.

all in the United States; the 30 men earned their degrees from 25 institutions and the 21 women earned their degrees from 16 institutions.

There are four scholars each who earned their degrees from the University of California-Berkeley (3 men and 1 woman) and the University of Chicago (3 women and 1 man); three scholars each earned their degrees from Harvard University (all women), Ohio State University (2 men and 1 woman), and Stanford University (2 women and 1 man); two scholars each earned their degrees from Iowa State University (1man and 1 woman), University of Illinois-Urbana-Champaign, and Virginia Tech (both men). The remaining 28 scholars earned their degrees from 28 different institutions (Table 5).

There are four institutions ranked in the top 10 in the 2015 US News and World Report rankings of national universities: Harvard University (\#2), Columbia University, Stanford University, and the University of Chicago (all tied at \#4), and the University of Pennsylvania (\#8). There are three other institutions in the top 20: Northwestern University (\#13), Cornell University (\#15), and the University of California-Berkeley (\#20). There are three other institutions in the top 47: the University of Michigan-Ann Arbor (\#29), the University of IllinoisUrbana-Champaign (\#42), and the University of Wisconsin-Madison (\#47) (Table 5; also see Hartlep, 2014; Kaba, 2009: pp. 183-184).

The study by Hartlep (2014) identified the institutions where 369 endowed professors of education in colleges and universities in the United States earned their terminal/highest degrees. Hartlep (2014) breaks down the institutions into four categories based on the 2014 US News and World Report rankings: elite colleges/universities (top 25); competitive universities (26 - 50); general institutions (colleges/universities ranked 51 and lower); and other (institutions outside the US “... or a specialized institution, such as Saint Louis Institute of Music or Fuller Theological Seminary”). Of the 369 endowed professors, 167 (45.3\%) earned their terminal/highest degrees from elite colleges/universities (top 25 institutions); 104 (28.2\%) from general institutions; 84 (22.8\%) from competitive institutions (26 - 50); and 14 (3.8\%) from "other" institutions.

\subsection{Types of Terminal/Highest Degrees Earned by Black American Endowed and Distinguished Professors}

One must not be surprised that most people in the public might assume that since these are endowed and distinguished professors of education, they may be likely to earn most of their terminal/highest degrees as an Ed.D. However, Table 6 illustrates that is not the case. For example, Table 6 shows that 40 (78.4\%) of the 51 scholars earned a Ph.D. as their terminal degree; 10 (19.6\%) have an Ed.D.; and one (1.96\%) has an M.A. Among the 30 male scholars, 23 (76.7\% of men, but $45.1 \%$ of all 51 total scholars) have a Ph.D.; six (20\% of men, but $11.8 \%$ of total) have an Ed.D.; and one (3.3\% of men, but 1.96\% of total) has an M.A. Among the 21 female scholars, 17 (81\% of women, but $33.3 \%$ of all 51 total scholars) have a Ph.D.; and four (19.1\% of women, but $7.8 \%$ of total) have an Ed.D. (Table 6).

\subsection{Academic Field of Terminal/Highest Degrees Earned by Black American Endowed and Distinguished Professors of Education}

Many people in the general public or even in academia might assume that since these are endowed and distinguished professors of education, they may also be likely to earn all or almost all of their terminal/highest degrees 
Table 6. Type of terminal/highest degree earned by Black American endowed and distinguished professors of education, by sex, 2013-2014 academic year.

\begin{tabular}{ccccccccc}
\hline \multicolumn{1}{c}{$\mathrm{N}=3$} & & & & & & & \\
Type of Terminal/Highest Degree & Men & \% of Men & \% of Total & Women & \% of Women & \% of Total & Total & \% \\
\hline Ed.D. & 6 & 20 & 11.8 & 4 & 19.1 & 7.8 & 10 & 19.6 \\
Ph.D. & 23 & 76.7 & 45.1 & 17 & 81 & 33.3 & 40 & 78.4 \\
M.A. & 1 & 3.3 & 1.96 & 0 & 0 & 0 & 1 & 1.96 \\
Total & 30 & 100 & 58.86 & 21 & 100.1 & 41.1 & 51 & 99.96 \\
\hline
\end{tabular}

Source: Compiled and computed based on data from: Hartlep, Nicholas D., and Theodosopoulos, Kendra, 2014, October 9. “African Americans who Hold Endowed and Distinguished Professorships in Education,” Journal of Blacks in Higher Education. Retrieved from October 12 2014 and November 22, 2014 from: http://www.jbhe.com/2014/10/african-americans-who-hold-endowed-and-distinguished-professorships-in-education/.

in the field of education. This is especially also as noted above in the introduction, a substantial proportion of doctorate degrees awarded to Black Americans is in the field of education (36.3\% in 2009). Table 7 illustrates that not to be the case. According to Table 7, these 51 scholars earned their terminal/highest degrees in nine different academic fields or majors. Of the 51 scholars, 35 (68.6\%) earned their terminal/highest degrees in the field of Education; six (11.8\%) in Psychology; three (5.9\%) in Sociology; 2 (3.9\%) in Language, Literature, and Culture; and one each (1.96) in Economics; English; Family and Child Development; Human development and Family Studies; and Social Policy and Evaluation Research.

Among the 30 male scholars, 20 (66.7\% of men, but 39.2\% of total) earned their terminal/highest degrees in the field of education; three (10\% of men, but $5.9 \%$ of total) each earned their terminal degrees in Psychology and Sociology; and one (3.3\% of men, but $1.96 \%$ of total) each earned a terminal/highest degree in Language, Literature and Culture; English; Family and Child development Studies; and Social Policy and Evaluation Research.

Among the 21 female scholars, 15 (71.4\% of women, but 29.4\% of total) earned their terminal/highest degrees in the field of education; three (14.3\% of women, but $5.9 \%$ of total) earned their degrees in Psychology; and one (4.76\% of women, but, $1.96 \%$ of total) each her degree in Language, Literature and Culture; Economics; and Human Development and Family Studies (Table 7).

\subsection{Year of Graduation with Terminal/Highest Degrees by Black American Endowed and Distinguished Professors of Education}

One factor that can explain whether a scholar is appointed to an endowed or distinguished professorship is age, meaning the older a scholar is, the more likely he or she is to be an endowed or distinguished professor (also see Kaba, 2009: pp. 175-176). Although the age data of the scholars in this study are not available, one can use the year of terminal/highest degree attainment as a proxy for age. According to Table 8, all 51 scholars earned their terminal/highest degrees from the years 1968 to 2012, with all of them earning their degrees in 31 different years.

Two male scholars earned their degrees in the 1960s (1968 and 1969). Eleven (21.6\%) scholars (6 men and 5 women) earned their degrees in the 1970s (1972-1976, 1978 and 1979), with two men earning their degrees in 1973. Twelve (23.5\%) scholars (7 men and 5 women) earned their degrees in the 1980s (1981, 1983, 1984, 1985, and 1987-1989), with three men doing so in 1985 and three women doing so in 1988. Thirteen scholars (25.5\%) (8 women and 5 women) earned their degrees in the 1990s (1990-1993, and 1995-1998), with two men and two women doing so in 1991.Another 13 (25.5\%) scholars (10 men and 3 women) earned their degrees from 2000 to 2012 (2000-2005, and 2012), with three men each doing so in 2000 and 2001. A total of four scholars each earned their degrees in 1988, 1990, and 2000; three of them did so in 1985 and 2001 (Table 8).

\subsection{US States Where Black American Endowed and Distinguished Professors of Education Earned Their Terminal/Highest Degrees}

It is worth noting that just as the 51 scholars in this study were employed in 21 states during the 2013-2014 academic year, so also all 51 of them earned their terminal/highest degrees in 21 states. There were nine (17.6\%) scholars each who earned their degrees in California (5 men and 4 women) and Illinois (5 men and 4 women). 
Table 7. Academic field of terminal/highest degree earned by Black American endowed and distinguished professors of education, by sex, 2013-2014 academic year.

\begin{tabular}{|c|c|c|c|c|c|c|c|c|}
\hline$N=9$ & & & & & & & & \\
\hline $\begin{array}{c}\text { Academic Field of Terminal/ } \\
\text { Highest Degree }\end{array}$ & Men & $\%$ of Men & $\%$ of Total & Women & \% or Women & $\%$ of Total & Total & $\%$ \\
\hline Education & 20 & 66.7 & 39.2 & 15 & 71.4 & 29.4 & 35 & 68.6 \\
\hline Psychology & 3 & 10 & 5.9 & 3 & 14.3 & 5.9 & 6 & 11.8 \\
\hline Sociology & 3 & 10 & 5.9 & 0 & 0 & 0 & 3 & 5.9 \\
\hline Language, Literature and Culture & 1 & 3.3 & 1.96 & 1 & 4.76 & 1.96 & 2 & 3.9 \\
\hline Economics & 0 & 0 & 0 & 1 & 4.76 & 1.96 & 1 & 1.96 \\
\hline English & 1 & 3.3 & 1.96 & 0 & 0 & 0 & 1 & 1.96 \\
\hline Family and Child Development & 1 & 3.3 & 1.96 & 0 & 0 & 0 & 1 & 1.96 \\
\hline $\begin{array}{l}\text { Human Development and } \\
\text { Family Studies }\end{array}$ & 0 & 0 & 0 & 1 & 4.76 & 1.96 & 1 & 1.96 \\
\hline $\begin{array}{c}\text { Social Policy \& Evaluation } \\
\text { Research }\end{array}$ & 1 & 3.3 & 1.96 & 0 & 0 & 0 & 1 & 1.96 \\
\hline Total & 30 & 99.9 & 58.8 & 21 & 99.98 & 41.2 & 51 & 100 \\
\hline
\end{tabular}

Source: Compiled and computed based on data from: Hartlep, Nicholas D., and Theodosopoulos, Kendra, 2014, October 9. “African Americans who Hold Endowed and Distinguished Professorships in Education,” Journal of Blacks in Higher Education. Retrieved from October 12 2014 and November 22, 2014 from: http://www.jbhe.com/2014/10/african-americans-who-hold-endowed-and-distinguished-professorships-in-education/; Note: It is important to point out that there are many subfields within the field of Education degrees and the other fields listed in the table among these scholars. For example, as presented in their CVs, web sites, etc., these are the various sub-fields that these scholars earned their Education degrees in for the men: History of Education; Social Studies Education; Leadership Studies Education; Higher Education Administration and College Teaching; Multi-Cultural and Equity Education; Urban and Curriculum Education; Educational Administration; Educational Policy and Research; Science and Mathematics Education; Higher Education Management; Educational leadership; Higher Education; Sociological Foundations of Education; Education Leadership and Policy Studies; Teacher Education/Education Leadership; Educational Administration and Policy Analysis; Counselor Education; and Mathematics Education. Two scholars just listed: Education. For Sociology, all three just listed: Sociology. For Psychology, they listed: Psychology; Counseling Psychology; and Clinical Psychology. Finally, four different scholars listed the following: English (Language, Literacy and Rhetoric); Language, Literacy, and Culture; Family and Child Development; and Social Policy and Evaluation Research. For the women: Curriculum and Instruction (two of them); Curriculum, Instruction and Professional Development; Urban Education; Multicultural Education/Language, Literacy and Culture/and Education Administration; Educational Psychology and Policy; Social Foundations of Education; Curriculum and Teacher Education; Sociology of Education; Special Education; Education Leadership and Policy Studies; and Mathematics Education. Three scholars listed only: Education. Three scholars listed: Psychology; Child and Developmental Psychology; and Counseling Psychology. The remaining three fields listed are: Economics; Human Development and Family Studies; and Language, Literacy, and Culture (also see Oplatka, 2010).

There were four (7.8\%) scholars who earned their degrees in Ohio (3 men and 1 woman); three (5.9\%) scholars each in Iowa (2 men and 1 woman) Massachusetts (3 women), and Michigan (2 men and 1 woman); two (3.9\%) scholars each in Missouri (1 man and 1 woman), New York (2 men), Pennsylvania (1 man and 1 woman), Wisconsin (2 men), and Virginia (2 men); and one (1.96\%) each in Arkansas (a man), Colorado (a man), Georgia (a woman), Louisiana (a man), Maryland (a man), Mississippi (a woman), Oklahoma (a woman), Oregon (a man), Texas (a woman), and Washington (a woman) (Table 9; also see Kaba, 2009: p. 173).

\subsection{US Regions Where Black American Endowed and Distinguished Professors of Education Earned Their Terminal/Highest Degrees}

The Midwest and the West combined are the two regions where these scholars earned over six out of every 10 of their terminal/highest degrees. Table 10 illustrates that 23 (45.1\% of the 51 scholars) scholars earned their degrees at institutions located in the Midwest; 12 (23.5\%) in the West; nine (17.7\%) in the South; and seven (13.7\%) in the Northeast.

Among the 30 male scholars, 15 (50\% of men, but 29.4\% of 51 total) earned their degrees in the Midwest; seven (23.3\% of men, but $13.7 \%$ of total) in the West; five (16.7\% of men, but $9.8 \%$ of total) in the South; and three $(10 \%$ of men, but $5.9 \%$ of total) in the Northeast. Among the 21 female scholars, eight (38.1\% of women, but $15.7 \%$ of total) earned their degrees in the Midwest; five (23.8\% of women, but $9.8 \%$ of total) in the West; 
Table 8. Year of graduation with terminal/highest degrees by Black American endowed and distinguished professors of education, by sex, 2013-2014 academic year.

\begin{tabular}{|c|c|c|c|}
\hline$N=31$ & & & \\
\hline Terminal/Highest Degree & Men & Women & Total \\
\hline 1968 & 1 & 0 & 1 \\
\hline 1969 & 1 & 0 & 1 \\
\hline 1972 & 1 & 1 & 2 \\
\hline 1973 & 2 & 0 & 2 \\
\hline 1974 & 0 & 1 & 1 \\
\hline 1975 & 1 & 1 & 2 \\
\hline 1976 & 1 & 1 & 2 \\
\hline 1978 & 0 & 1 & 1 \\
\hline 1979 & 1 & 0 & 1 \\
\hline 1981 & 1 & 0 & 1 \\
\hline 1983 & 1 & 0 & 1 \\
\hline 1984 & 0 & 1 & 1 \\
\hline 1985 & 3 & 0 & 3 \\
\hline 1987 & 0 & 1 & 1 \\
\hline 1988 & 1 & 3 & 4 \\
\hline 1989 & 1 & 0 & 1 \\
\hline 1990 & 1 & 1 & 2 \\
\hline 1991 & 2 & 2 & 4 \\
\hline 1992 & 0 & 1 & 1 \\
\hline 1993 & 0 & 1 & 1 \\
\hline 1995 & 1 & 0 & 1 \\
\hline 1996 & 0 & 1 & 1 \\
\hline 1997 & 1 & 1 & 2 \\
\hline 1998 & 0 & 1 & 1 \\
\hline 2000 & 3 & 1 & 4 \\
\hline 2001 & 3 & 0 & 3 \\
\hline 2002 & 1 & 1 & 2 \\
\hline 2003 & 0 & 1 & 1 \\
\hline 2004 & 1 & 0 & 1 \\
\hline 2005 & 1 & 0 & 1 \\
\hline 2012 & 1 & 0 & 1 \\
\hline Total & 30 & 21 & 51 \\
\hline
\end{tabular}

Source: Compiled and computed based on data from: Hartlep, Nicholas D., and Theodosopoulos, Kendra, 2014, October 9. "African Americans who Hold Endowed and Distinguished Professorships in Education,” Journal of Blacks in Higher Education. Retrieved from October 122014 and November 22, 2014 from: http://www.jbhe.com/2014/10/african-americans-who-hold-endowed-and-distinguished-professorships-in-education/. 
Table 9. US States where Black American endowed and distinguished professors of education earned their terminal/highest degrees, by sex, 2013-2014 academic year.

\begin{tabular}{|c|c|c|c|c|}
\hline$N=21$ & & & & \\
\hline State of Terminal/Highest Degree & Men & Women & Total & $\%$ \\
\hline California & 5 & 4 & 9 & 17.6 \\
\hline Illinois & 5 & 4 & 9 & 17.6 \\
\hline Ohio & 3 & 1 & 4 & 7.8 \\
\hline Iowa & 2 & 1 & 3 & 5.9 \\
\hline Massachusetts & 0 & 3 & 3 & 5.9 \\
\hline Michigan & 2 & 1 & 3 & 5.9 \\
\hline Missouri & 1 & 1 & 2 & 3.9 \\
\hline New York & 2 & 0 & 2 & 3.9 \\
\hline Pennsylvania & 1 & 1 & 2 & 3.9 \\
\hline Wisconsin & 2 & 0 & 2 & 3.9 \\
\hline Virginia & 2 & 0 & 2 & 3.9 \\
\hline Arkansas & 1 & 0 & 1 & 1.96 \\
\hline Colorado & 1 & 0 & 1 & 1.96 \\
\hline Georgia & 0 & 1 & 1 & 1.96 \\
\hline Louisiana & 1 & 0 & 1 & 1.96 \\
\hline Maryland & 1 & 0 & 1 & 1.96 \\
\hline Mississippi & 0 & 1 & 1 & 1.96 \\
\hline Oklahoma & 0 & 1 & 1 & 1.96 \\
\hline Oregon & 1 & 0 & 1 & 1.96 \\
\hline Texas & 0 & 1 & 1 & 1.96 \\
\hline Washington & 0 & 1 & 1 & 1.96 \\
\hline Total & 30 & 21 & 51 & 99.8 \\
\hline
\end{tabular}

Source: Compiled and computed based on data from: Hartlep, Nicholas D., and Theodosopoulos, Kendra, 2014, October 9. “African Americans who Hold Endowed and Distinguished Professorships in Education,” Journal of Blacks in Higher Education. Retrieved from October 12 2014 and November 22, 2014 from: http://www.jbhe.com/2014/10/african-americans-who-hold-endowed-and-distinguished-professorships-in-education/.

Table 10. US regions where Black American endowed and distinguished professors of education earned their terminal/ highest degrees, by sex, 2013-2014 academic year.

\begin{tabular}{|c|c|c|c|c|c|c|c|c|}
\hline $\begin{array}{c}\text { Region of earned Terminal/ } \\
\text { Highest Degree }\end{array}$ & Men & $\%$ of Men & $\%$ of Total & Women & $\%$ of Women & \% of Total & Total & $\%$ \\
\hline Northeast & 3 & 10 & 5.9 & 4 & 19.1 & 7.8 & 7 & 13.7 \\
\hline Midwest & 15 & 50 & 29.4 & 8 & 38.1 & 15.7 & 23 & 45.1 \\
\hline South & 5 & 16.7 & 9.8 & 4 & 19.1 & 7.8 & 9 & 17.7 \\
\hline West & 7 & 23.3 & 13.7 & 5 & 23.8 & 9.8 & 12 & 23.5 \\
\hline Total & 30 & 100 & 58.8 & 21 & 100.1 & 41.1 & 51 & 100 \\
\hline
\end{tabular}

Source: Compiled and computed based on data from: Hartlep, Nicholas D., and Theodosopoulos, Kendra, 2014, October 9. “African Americans who Hold Endowed and Distinguished Professorships in Education,” Journal of Blacks in Higher Education. Retrieved from October 12 2014 and November 22, 2014 from: http://www.jbhe.com/2014/10/african-americans-who-hold-endowed-and-distinguished-professorships-in-education/. 
and four (19.1\% of women, but 7.8\% of total) each in the Northeast and South (Table 10; also see Kaba, 2009: p. 174).

\section{Discussion}

The data presented in the tables above tell many important stories about not only the gradual progress of Black American professors in the field of education, but also about Black Americans in higher education and society in general. For example, all 51 scholars earned their terminal/highest degrees at institutions in the United States. economists, sociologists and psychologists are among the 51 scholars. The Ph.D. degree is the most common among these scholars, with almost four out of every five of them earning that degree. Many of the institutions where these scholars are employed or earned their terminal/highest degrees are among the most selective institutions not just in the United States, but the entire world.

For this discussion section, however, I will focus on the following important findings: 1) the gender gap among the 51 scholars; 2) the predominance of the South and Midwest regions of the United States as the regions of employment and terminal/highest degree attainment of these endowed and distinguished professors of education; 3) the relative underrepresentation of Ivy League institutions; and 4) the visible underrepresentation of Historically Black Colleges and Universities (HBCUs).

\subsection{Gender Gap between Black Endowed and Distinguished Professors of Education}

The ongoing gender gap between Black male and Black female professionals in the United States goes beyond race and higher education. This is observed in politics, religion, business, etc. Men in general tend to be recognized more than their female counterparts, just as Black men tend to be recognized more than their female counterparts. For example, no woman has been president of the United States; there are only three women among the nine justices of the United States Supreme Court, with no Black woman among them; in addition to women being a small minority in both houses of the US Congress, there is no Black female member of the US Senate, but two Black male members; There is not a single Black female governor among the fifty states of the Union (Kaba, 2013c). Kaba's (2012c) study of the Root Magazine's (an African American magazine owned in 2011 by the Washington Post newspaper) 2011 most influential young Black Americans (ages 25 to 45) entitled: "Talented Tenth: An Analysis of the 2011 Root Magazine’s 100 Most Influential Young Black Americans" shows that 66 were men and 34 were women (p. 7).

In this study, women accounted for 21 ( $41.2 \%$ of the 51 scholars). Of the 378 endowed professors of education in Hartlep’s (2014) study, men accounted for 220 (58.2\%) and women accounted for 158 (41.8\%). Hartlep (2014) adds that: "This male advantage was present among all racial groups, as was clearly the case in Asian American endowed professors of education.” Stone's (2001) study finds that: "Of the 129 chaired professorships, women hold about 30 percent, a number that undercuts the increasing percentage of African-American women assistant, associate, and full professors that is slowly approaching parity” (p. 121). Kaba's (2009) study of the Journal of Blacks in Higher Education 2009 list of the most cited Black professors and scholars in the social sciences, arts and humanities (58 total) shows that men accounted for 37 (63.8\%) and women accounted for 21 (36.2\%) (p. 162).

What are some explanations for the gender gap in this current study? One factor could be age. As Table 8 shows, there are more males (15) who earned their terminal/highest degrees from the 1960s to the 1980s combined than their female (10) counterparts. Hartlep (2014) points out that of the 278 endowed professors for whom data of year or date of graduation were available, "The average length of time between graduation and receiving an endowed position was 20.3 years $(S D=9.2)$." Although on average Black females are older than Black males in general, Black men were accepted into many higher education institutions before Black women. In 2011, of the 28.6 million Black Americans aged 18 and over, women accounted for 53.5 percent. Of the 3.6 million Black Americans aged 65 and over, women accounted for $60.7 \%$ ("Selected Population Profile in the United States," 2013). At the time when W.E.B. Du Bois earned his Ph.D. from Harvard in 1895, and John Hope Franklin earned his Ph.D. from Harvard in 1941, no Black woman had been given such an opportunity. But in academia, there is no age limit as to how long a professor can teach. For example, John Hope Franklin taught from 1941 until his death in 2009 (also see Gates Jr., 2009).

Also, although by the middle of the second decade of the twenty-first century, within the Black American population, women are now the majority among those enrolled in college, those who earned higher education 
degrees, and among Black faculty, because they have been allowed into higher education in large numbers starting just in the 1970s, Black men still have more privilege positions in higher education. For example, in October 2012, there were 2.043 million Black females enrolled in colleges and universities in the United States (9.4\% of Black females aged 3 and over) and 1.292 million Black males were enrolled in college (6.8\% of Black males aged 3 and over). In October 2012, there were 2.145 million Black women aged 18 and over with a bachelor's degree, 946,000 with master's degrees, 121,000 with professional degrees, and 105,000 with doctorate degrees. For Black men, the figures were 1.522 million bachelor's degrees, 470,000 master's degrees, 105,000 professional degrees, and 124,000 doctorate degrees. Of the 2567 doctorate degrees awarded to Blacks in 2012 by colleges and universities in the United States, women accounted for 1492 (58.1\%) (Kaba, 2014: pp. 79-100).

Among Black faculty in degree granting higher education institutions in the United States, by 2011, there were more women than men. Of the 41,649 Black faculty in 2011, women accounted for 22,989 (55.2\%). However, in 2011, of the 6517 Black Full Professors, men accounted for 3984 (61.1\%) and women accounted for 2533 (38.1\%). Of the 8695 Black Associate Professors in 2011, men accounted for 4373 (50.3\%) and women accounted for 4322 (49.7\%) (“Table 315.20. Full-Time Instructional Faculty in Degree-Granting," 2014). Full and Associate professors tend to have earned tenure, and it is among these groups where endowed and distinguished professors are normally selected.

According to Gardner and Blackstone (2013): "Women at the rank of professor in four-year institutions constituted only $26 \%$ of the total in $2009-2010 \ldots$ women faculty members 'stand still at associate'... Moreover, when they finally do advance to full professor, it may have taken up to $24.2 \%$ longer than for men” (p. 413). This is especially the case for Black women in US colleges and Universities. Among the many interrelated factors cited for the underrepresentation of Black women as associate and full professors, which lead to fewer of them appointed as endowed or distinguished professors are: mentoring, bullying, institutional climate, sexism, racism, culture, socialization, collegiality, networking, organizational or institutional support, recognition of their research, funding/grants, professional development, institutional isolation, and disrespected by colleagues and students (Alexander \& Moore, 2008; Carson III, 2013; Frazer, 2011; Evans, 2007; Evans \& Cokley, 2008; Griffin, 2012; Gardner \& Blackstone, 2013; Griffin, 2013; Harley, 2008; Jones \& Osborne-Lampkin, 2013; Lemelle Jr., 2010; Warde, 2009).

According to Alexander and Moore (2008): “... African American faculty also faces many challenges at PWIs [Predominantly White Institutions]. There are often emotional, legal, psychological, physical, social and spiritual consequences that they suffer as a result of working at these institutions. They often work in isolation, are not privy to informal networks and sources of information, and have their work and ideas devalued" (p. 2). López and Johnson (2014) note that: "women of color in particular experience differential treatment by university leaders, faculty, and students of the campus community. In their eyes, they experience nothing less than a hostile working environment” (p. 391).

The factors presented in the explanations above have contributed substantially to the underrepresentation of Black female faculty among endowed and distinguished professors not only in the field of education, but in higher education in general. Black women pay a triple penalty of race, gender and class. The race and gender examples have been presented above. One example of class is that in 2009, of the 16,054,000 Black female households in the United States, 6,167,000 (38.4\%) earned under \$10,000; only 10,000 Black female households earned \$250,000 or above in 2009. For 13,314,000 Black male households, 5,020,000 (37.7\%) earned under $\$ 10,000$; but 62,000 Black male households earned \$250,000 and above. For 99,380,000 White female households, 35,137,000 (35.4\%) earned under \$10,000; 244,000 earned \$250,000 or more. For 96,190,000 White male households, 20,216,000 (21\%) earned under \$10,000; and 1,037,000 (1.1\%) earned \$250,000 or more ("Table 705. Money Income of People-Number by Income Level and by Sex, Race, and Hispanic Origin: 2009," 2012).

\subsection{High Representation of the South and Midwest Regions of the United States}

As Table 4 and Table 10 illustrate, both the American South and the Midwest regions appear to be very central when it comes to the employment and the conferring of terminal/highest degrees to the 51 Black endowed and distinguished professors of education in this study. This development deserves some discussion because one would normally have expected the Northeast and West regions of the country to have employed the overwhelming majority of these scholars and also where the overwhelming majority of them would have earned their ter- 
minal/highest degrees. In fact, as Table 4 shows, the Northeast employed a sizable or respectable number or proportion of the scholars (13 or 25.5\%), but one expected the region to have done more because of the very large number of great colleges and universities in that region. The West employed only 5 (9.8\%) of the scholars despite the abundance of great colleges and universities in that region of the country, including California, which in fact employed four of the five scholars employed in the West. For example, of the 54 US institutions among the top 200 universities in the world, 18 (33.3\%) were located in the Northeast; and 12 (22.2\%) each in the Midwest, South and West (Kaba, 2012b: p. 13). The study by Stone (2001) also makes this observation: "Probably the biggest surprise in this quadrennial census is the notability of four southern universities ranking very high in the number of African-American chaired professorships - the University of North Carolina at Chapel Hill with nine, the University of Texas with seven; Emory University with six, and Duke University with five” (p. 121).

In terms of where these scholars earned their terminal/highest degrees, as Table 10 illustrates, both the South and Midwest regions combined accounted for 32 (62.8\%) of the 51 scholars, with the Midwest accounting for 23 (45.1\%) of all 51 scholars. Again, although the West accounted for a respectable 12 (23.5\%), one would have expected both the West and the Northeast combined to account for far more than their 19 (37\%) total. The question then is: why the South and Midwest? Let us attempt to briefly answer this question by looking at each of these two regions one at a time.

\subsection{The South-Historical and Cultural Home of Black Americans}

One can point to a number of important interrelated factors responsible for such a substantial number or proportion of Black endowed and distinguished professors of education to be employed in the South and also to earn their terminal/highest degrees in that region of the country. One of those factors is that the South has historically been home to the vast majority of Black Americans. Even with the great mass migration of Blacks to other parts of the country in the 1900s including during both World Wars, the region still is home to the majority of Black Americans. In addition, from the 1990s to present, substantial numbers of Black Americans have been relocating back (reverse migration) to the South from other parts of the country. According to Hobbs and Stoops (2002), in 1900, the South accounted for almost nine (89.7\%) out of every 10 Black Americans (p. 83). Although the great Black American migration reduced that proportion substantially to $53.6 \%$ in 2000, by the 2010 US Census, of the 42 million Black or African American alone or in combination with another race, 55\% resided in the South; $18.1 \%$ in the Midwest; $17.1 \%$ in the Northeast; and 9.8\% in the West. Of the top 10 places in the United States with population of 100,000 or more with the highest proportion of Black Americans in 2010, eight of them are in the South: Detroit, MI (84.3\%); Jackson, MS (80.1\%); Miami Gardens, FL (77.9\%); Birmingham, AL (74\%); Baltimore, MD (65.1\%); Memphis, TN (64.1\%); New Orleans, LA (61.2\%); Flint, MI (59.5\%); Montgomery, AL (57.4\%); and Savannah, GA (56.7\%) (Rastogi, 2011: p. 8).

Most Blacks returning to the South do so to be closer to family members or cultural ties, economic opportunities, low cost of living, and the climate. Writing about the Black American reverse migration to the South, William H. Frey (2011) points out that: “... the Great Migration from South to North, and large concentrations in segregated city neighborhoods - are undergoing a dual reversal. The first reversal took hold in the 1990s, but continues in full force: a pronounced shift "back" to the South. Economic progress, cultural ties, and an emerging black middle class have driven greater numbers of blacks to prosperous southern metropolitan areas like Atlanta, Dallas, Houston, and Raleigh.” Copeland (2011) quoted a Black American female professional who had moved to Florida from New York with her husband as saying that, "It was also an economic decision. We were able to buy a house here that we wouldn't have been able to afford in New York” (p. 1A). Copeland (2011) notes that Black Americans: “... are drawn south by the lure of jobs, by the prospect of making their money go further, by the warm climate and other amenities, and by family ties. In some cases, they felt a cultural pull of a region their forebears left decades ago” (p. 1A). Copeland (2011) adds by quoting a scholar named Silas Lee at Xavier University in New Orleans that Black Americans are going back to their "ancestral home” and that "This (the South) really is the family roots for the majority of African Americans anywhere in the country...” (p. 1A).

\subsection{The Midwest-Illinois as a Promise Land}

Just as when gold was discovered in California in the 1848-1855 period, there used to be a saying in the east of the United States “Go West, young man, go West”, there might have been the saying to Black Americans before 
and after slavery and emancipation "Go Midwest, Negro, go Midwest”. Many of the most prominent, wealthy and influential or powerful Black Americans from all walks of life moved to the Midwest to build their careers or were born there. From President Barack Obama to first lady Michelle Obama, Oprah Winfrey, Michael Jordan, Jesse Jackson, Louis Farrakhan, former US Senator Carol Mosely Braun, the singer and entertainer Prince, the late Michael Jackson and his siblings and parents, former US Senator Roland Burris, the late Harold Washington, the first and only Black mayor of Chicago, and even the late Dr. Martin Luther King, Jr. spent time in the Midwest (Illinois), when he established the Chicago Freedom Movement. As Merda (2014) points out, "Martin Luther King, Jr. spent a significant amount of time in Chicago fighting City Hall, school segregation... One of King's biggest impacts was the Chicago Freedom Movement, which fought against deplorable conditions that blacks were forced to live in because of housing segregation. And that fight helped bring about the Fair Housing Act, which was enacted on April 11, 1968-less than a week after King's assassination” (also see Beltramini, 2014; Keating, 2014; Ralph Jr., 1993; Shaw, 2001). Explaining the Midwest's region, especially Illinois as a form of promise land for Black Americans, one can point to the period before the American Civil War, when even enslaved Blacks would consider themselves free if their owners were to travel with them to that region because most of it was already free during that period. For example, in the famous US Supreme Court case Dred Scott Decision: “...the enslaved Dred Scott, having been taken by his master into free territory [Illinois and what is today Minnesota], sues in1846 for his freedom under the prevailing law of slave transit, wins in the lower court, but eventually loses in a 1857 US Supreme Court ruling. Led by Chief Justice Roger Taney, the court overturns the Missouri Compromise and Northwest Ordinance and denies any legal rights to African Americans, slave or free" (Vander Velde, 2011: p. 25). As Copeland (2011) notes, in the first few decades of the twentieth century Black Americans: “...began fleeing the region [the South] in massive numbers, escaping 'sharecropping, worsening economic conditions and the lynch mob' and seeking 'higher wages, better homes and political rights'” (p. A1).

Blocker (2008) points out that 750,000 Black Americans migrated from the South to the Lower Midwest between 1860 and 1930 (p. 10). Keating (2014) writes of the many influential Black American religious leaders and "... thousands of other migrants headed to Chicago, most of them African American coming from the Deep South. From the late 1940s through the 1960s, a half million migrants came to Chicago and their arrival affected nearly every aspect of city life” (p. 45). This is the reason why as Rastogi et al. (2011) point out, by 2010 the Midwest region accounted for the second largest proportion or number of Black Americans (18.1\% or 7.6 million), with Illinois accounting for 1.974 million (26\% of the 7.6 million) (p. 8).

The examples presented above have contributed to our understanding of how a very high majority of Black endowed and distinguished professors in this study are employed in the South and the Midwest and also why a strong majority of them earned their terminal/highest degrees in those two regions. This shows that history is never too far away from people in general. To understand one's current situation, one must understand their history.

\subsection{Underrepresentation of Ivy League Institutions}

It is important to discuss the underrepresentation of America's eight Ivy League institutions (Brown University, Cornell University, Dartmouth College, Columbia University, Harvard University, Princeton University, University of Pennsylvania, and Yale University) among the institutions employing the 51 Black endowed and distinguished professors of education in this study, and also their underrepresentation among the institutions conferring terminal/highest degrees to these 51 scholars. Of the eight Ivy League institutions, three employed 5 Black endowed and distinguished professors for the 2013-2014 academic year: two (both women) by Harvard University; two (1 man and 1 woman) by the University of Pennsylvania; and one (a man) by Columbia University (Table 2). Six of these 51 scholars earned their terminal/highest degrees from four Ivy League institutions: three (all women) from Harvard University; and a male each from Cornell University, Columbia University, and the University of Pennsylvania (Table 5).

The reason for discussing this underrepresentation is that the eight Ivy League institutions are among the first colleges established in Colonial America, and they are all located in the Northeast region of the country, with the ancestors of these Black scholars actually contributing to physically build these institutions with their bare hands, or profits from the enslavement of their ancestors used to build these eight Ivy League institutions (Wilder, 2013). These eight institutions are among the wealthiest institutions in the country. For example, the endow- 
ment data provided by the US Department of Education for the 120 institutions in the US with the highest endowments in 2007 was $\$ 322.2$ billion. The total for the eight Ivy League institutions in 2007 was $\$ 98.7$ billion (30.6\% of the $\$ 322.2$ billion): Harvard University ( $\$ 34.6$ billion); Yale University ( $\$ 22.5$ billion); Princeton University (\$15.8 billion); Columbia University \$7.15 billion; University of Pennsylvania \$6.64 billion; Cornell University \$5.425 billion; Dartmouth College \$ 3.76 billion; and Brown University \$2.78 billion (Kaba, 2012b: pp. 26-29).

On the one hand, one can point to examples of Ivy League institutions employing Black faculty and accepting Black students more than most other Predominantly White Institutions. For example, Kaba's (2012c) study of the top 100 most influential young Black Americans aged 25 to 45 showed that 70 of them earned 72 bachelor's degrees; 31 of them earned 35 master's degrees; 13 of them earned 13 Juris Doctorate degrees; and nine of them earned 10 doctorate degrees, including a Medical Doctorate. Kaba (2012c) then claims that: "The degree attainment data in this study also show that 7 of the 8 Ivy League institutions (Brown University, Dartmouth College, Columbia University, Harvard University, Princeton University, University of Pennsylvania, and Yale University) (excluding only Cornell University) conferred dozens of bachelor's, master's, JD, and doctorate degrees combined to these young Black Americans" (pp. 18-25; also see Toch and Burke, 1993). Also, the study by Kaba (2009) of the Journal of Blacks in Higher Education most cited Black scholars in the social sciences, arts, and humanities in 2009 shows that of the 58 of them, total employment data for the 2008-2009 academic year were available for 56 of them. Of the 56 scholars, 26 (46.5\%) were employed by Ivy League institutions: " 10 (17.9\% of 56) at Harvard; 6 (10.7\%) at Princeton; 5 (8.9\%) at Yale; 2 each (3.6\%) at Columbia and the University of Pennsylvania; and $1(1.8 \%)$ at Brown University. Of the 26 professors and scholars employed at Ivy League institutions, 8 (14.3\% out of 56) are females: 3 (5.4\%) at Princeton; 2 (3.6\%) at Harvard; and 1 each (1.78\%) at Brown, Columbia and the University of Pennsylvania” (pp. 163 \& 165). In addition, of the 58 scholars, 17 (29.2\%) earned their terminal or highest degrees from Ivy League institutions: "Harvard, 8 (13.8\% out of 58), Yale, 4 (6.9\%), Princeton, 2 (3.4\%); and 1 each (1.7\%) from Columbia, Cornell, and the University of Pennsylvania. Of the 17 professors and scholars who earned their terminal or highest degrees from Ivy League institutions, 8 (13.8\% out of 58) are females: 5 (8.6\%) from Harvard, and 1 each (1.7\%) from Yale, Cornell and the University of Pennsylvania” (Kaba, 2009: p. 172). Of the 129 Black endowed professors in colleges and universities in the United States in Stone's (2001) study, seven were employed at Harvard University, and five each at Princeton University and the University of Pennsylvania (p. 121).

On the other hand, one can point to examples, including this current study where Ivy League institutions employ or accept very few to no Blacks or minorities in their different programs in their institutions ("Black Faculty at the Nation's Highest-Ranked Colleges and Universities," 2005; "News and Views: A JBHE Report Card on the Progress of Blacks," 2002; Stern, 2005; Unz, 2012). For example, Stern (2005) points out that, "Since 2003, Ivy League colleges have hired 433 new tenure-track professors, but only 14, or 3 percent, were African-American and eight, or 2 percent, were Hispanic.” (p. 19). Stern (2005) cites a scholar who claims that Ivy League institutions are known to mostly hire "senior faculty who have gained tenure at some elite university. They're not giving junior faculty or other institutions' junior faculty an opportunity to grow. They're bringing in people who have gained prestige" (p. 20). According to a 2002 survey by the Journal of Blacks in Higher Education, "Of the Ivy League universities, Princeton shows the poorest performance. Only 18 of the university's 789 full-time faculty members are black... At 2.0 percent, Yale has the lowest percentage of black tenured faculty among the Ivy League schools" ("News and Views: A JBHE Report Card on the Progress of Blacks," 2002: pp. 10-14). A 2005 survey by the Journal of Blacks in Higher Education of 28 high-ranking universities in the United States finds that in 2002, “... of the 400 professors with tenure at the Columbia [University] College of Arts and Sciences, only five were black..." ("Black Faculty at the Nation's Highest-Ranked Colleges and Universities," 2005). In 2005, "At 1.8 percent, Columbia has the lowest percentage of black tenured faculty among the Ivy League schools. Brown University has the highest percentage of blacks among its tenured faculty at 4.4 percent. At Dartmouth and Princeton, 3.1 percent of the tenured faculty is black ("Black Faculty at the Nation's Highest-Ranked Colleges and Universities," 2005: pp. 78-84). It has also been noted that harassment of Black endowed professors by White colleagues and some top administrators at Ivy League institutions causes them to move from institution to institution seeking a more tolerant academic community (Robertson, 2002).

Pertaining to this current study, a very good explanation for the underrepresentation of Ivy League institutions is that first the institution must have a department of education, or school or college of education. Second, it is important for Black faculty to actually be employed at such an entity of that Ivy League institution to have a 
chance to be appointed to an endowed or distinguished professorship. As of the fall semester of 2014, Cornell University, Princeton University and Yale University do not have an academic Department of Education, School of Education or College of Education. Dartmouth College has a Department of Education, but I identified no Black person among the full-time faculty members ("Dartmouth College: Department of Education," 2014). Brown University has a Department of Education, but I identified no Black person among the full-time faculty members ("Brown University: Department of Education," 2014).

Ivy League institutions also tend to hire from within their own institutions or other Ivy League institutions. For example, Kaba’s (2011) study entitled: “Demographics and Publication Productivity of Ivy League Political Science Professors: Harvard, Princeton, University of Pennsylvania and Yale” identified 210 total professors, with no more than eight Black professors. Of the 210 professors, data showing institution of graduation with terminal/highest degrees were available for 198 (94.3\%) of them. Of the 198 professors, 90 (45.4\%) earned their terminal/highest degrees from Ivy League institutions. I would call this phenomenon the "Academic Incest Model”- an institution educating or training its own future faculty and administrators (also see Franklin, 1990: p. 413).

\subsection{Underrepresentation of Historically Black Colleges and Universities (HBCUs).}

It is useful to briefly discuss the underrepresentation of Historically Black Colleges and Universities (HBCUs) in this study. Only one of the institutions where all 51 scholars are employed is an HBCU (Fayetteville State University). Also, only one of the institutions where all 51 scholars earned their terminal/highest degrees is an HBCU (Southern University_Baton Rouge). According to Clement and Lidsky (2011), there are currently 105 HBCUs in the United States (p. 150). A number of interrelated factors are responsible for this underrepresentation of HBCUs in this study. Let us examine some of these factors.

The first and most important factor is money or resources, and it is connected to any additional factors. HBCUs are struggling to survive because they lack funding. Compared with Predominantly White Institutions, they do not have the funding to establish sufficient endowed or distinguished chairs even for very talented scholars currently employed there (Cantey et al., 2013: pp. 145-148; Cottman, 2014; Hill, 2011; Johnson, 2013; Lesesne \& Stuart, 2013; Nealy, 2009; Palmer \& Griffin, 2009). According to Johnson (2013): “From their inception, HBCUs have experienced unequal treatment especially in the resource arena. This is particularly apparent in the treatment that public HBCUs face each fiscal year attempting to garner state resources from their legislative coffers compared with other institutions in their states” (p. 65). Another factor is that either many HBCUs do not have an education department, school or college, or they do not offer doctoral degrees in education.

Another factor is that even if HBCUs have the funding to establish endowed or distinguished chairs, many prominent Black scholars may not want to work there because they do not have the same "prestige" as the Predominantly White Institutions and certain academic programs are not accredited. In addition, the lack of prestige leads to graduates of HBCUs earning less than graduates from Predominantly White Institutions (Cantey et al., 2013: pp. 145-148; Fryer \& Greenstone, 2010; Irvine \& Fenwick, 2011; Jones, 2013). This results in being ranked relatively low among Tier One National Universities in the country, or not ranked in Tier One at all. For example, Howard University, one of the most respected and recognized HBCUs in the United States is the only HBCU ranked among Tier One National Universities (top 201 institutions in the country) in the 2015 US News and World Report rankings, at \#145 ("Best National Universities,” 2014: p. 76; also see Brown, 2014).

One factor that is most commonly cited is leadership and accountability from the presidency of HBCUs to the Boards that govern them and the legislators and governors that govern and fund especially the public institutions. Some HBCU presidents have been accused of not supporting academic freedom. They are also reported to be too conservative for academic institutions. All of these factors can keep talented Black faculty and students away (Abelman \& Dalessandro, 2009; Cantey et al., 2013: pp. 145-148: Gasman, 2010; Johnson, 2013: p. 65; Palmer \& Griffin, 2009; Taylor Jr., 2012). For example, Cantey et al. (2013) point out that in addition to funding and accreditation issues, HBCUs also have a challenge in leadership, which they note is linked to funding. They claim that strong leadership is necessary for the survival of HBCUs and that HBCUs leaders need to find ways to improve fundraising for the institutions they lead, which will lead to increased academic achievements. The authors add that: "The selection of the president in HBCUs has been too political, with the governor, Board of Regents, and legislators playing games that are designed to select weak leaders so that the HBCU would not excel” (p. 148). 
Discussing the leadership challenges at HBCUs, Gasman (2010) claims that eight of these institutions have been censured by the American Association of University Professors (AAUP) in the past quarter century due to governance and academic freedom violations. These eight HBCUs represent over one out of every five (21\%) of all institutions that have been censured in this manner, and that in each case it was faculty members at those institutions that filed complaints against the leaderships of those entities. One example, according to Gasman (2010), involves shared governance, academic freedom and tenure, and it happened at Clark Atlanta University in Georgia, on February 6, 2009 when without any notice, the president of that HBCU terminated 55 full-time faculty members, many of whom already had tenure. A number of these terminated faculty members, who were forced to immediately leave the institution, were tenured associate professors who had been serving there for over 15 years earning \$45,000 a year. Gasman (2010) adds that while the president of the university claims that the terminations were due to financial reasons because of enrollment problems, “...he refused to claim 'financial exigency': a situation in which an institution's finances are so unstable that it is deemed appropriate to take action in the form of eliminating tenured faculty positions without ample warning” (p.55). Discussing the issue of leadership and the perception of presidents at HBCUs, Nichols (2004) quotes a scholar as saying, "as late as the 1960s, the HBCUs as a group suffered from stereotypes of presidents who rode around in limousines and lived in mansions while their colleges verged on the brink of fiscal disaster” and “...that many of the problems on the campuses of HBCUs seem to be related to leadership”. Nichols (2004) adds that: “A number of former and current HBCU presidents, trustees, and other leaders, agreed that the presidents of the future must have a firm understanding of the academic enterprise, management, finances, personnel administration, information systems, and planning” (pp. 22-23).

\section{Conclusion}

This study begins by discussing the gradual progress that Black Americans have made in increasing their numbers among the faculty at colleges and universities in the past several decades. By 2011, there were over 41,000 Black faculty members at colleges and universities in the United States. Within the professoriate, Blacks have also made significant progress in earning tenure and promotion to associate and full professor positions. It is among associate and full professor positions that Blacks have also made some progress in earning appointments to endowed and distinguished professorships, including in the field of education. The study claims that the increase in tolerance in the United States is a major contributing factor for the increase in Black endowed professors in colleges and universities in the country.

The study shows that of the 51 Black endowed and distinguished professors, men accounted for the majority. The South and Midwest regions of the United States are where a strong majority of these 51 scholars are employed or earned their terminal/highest degrees. Almost 70\% of these scholars earned their degrees in education, and the Ph.D. degree was the most common among them. None of the scholars earned their terminal or highest degrees outside the United States. Ivy League institutions are relatively underrepresented, and only one each HBCU institution is represented among the institutions of employment and institution where they earn their terminal/highest degree.

A number of factors are presented for the gender gap in this study, including age, and difficulty that Black women face in earning tenure and promotion to associate and full professor positions. Among the factors presented for the strong presence of the South and Midwest regions are that both regions have the two highest proportions of Black Americans, with the South accounting for the majority of Blacks; the uniqueness of the state of Illinois as a place of real opportunities for Black Americans. Ivy League institutions are relatively underrepresented because of their hiring practices, including hiring their own graduates or those from other Ivy League institutions; and the absence of an education department, or school or college. The primary reason for the underrepresentation of HBCUs in this study is lack of money or resources. Another important factor commonly cited is leadership at HBCUs.

\section{References}

Abelman, R., \& Dalessandro, A. (2009). The Institutional Vision of Historically Black Colleges and Universities. Journal of Black Studies, 40, 105-134. http://dx.doi.org/10.1177/0021934707307828

Agiesta, J., \& Ross, S. (2012) AP Poll: Majority Harbor Prejudice against Blacks. New York City, NY: Associated Press. http://news.yahoo.com/ap-poll-majority-harbor-prejudice-against-blacks-073551680-election.html 
Alexander, R., \& Moore, S. E. (2008). Introduction to African Americans: Benefits and Challenges of Working at Predominantly White Institutions: Strategies for Thriving. Journal of African American Studies, 12, 1-3. http://dx.doi.org/10.1007/s12111-007-9027-0

Almond, B. (2010). Education for Tolerance: Cultural Difference and Family Values. Journal of Moral Education, 39, 131-143. http://dx.doi.org/10.1080/03057241003754849

Barbezat, D. A. (2006). Gender differences in Research Patterns among PhD Economists. Journal of Economic Education, 37, 359-375. http://dx.doi.org/10.3200/JECE.37.3.359-375

Beltramini, E. (2014). Jesse Jackson and the Globalization of Black Business. The Journal of International Management Studies, 9, 1-12.

Best National Universities (2014). US News and World Report Rankings, Best Colleges (15th ed., pp. 66-180). http://colleges.usnews.rankingsandreviews.com/best-colleges

Black Faculty at the Nation’s Highest-Ranked Colleges and Universities (2005). Journal of Blacks in Higher Education, 48, 78-84.

Blocker, J. S. (2008). A Little More Freedom: African Americans Enter the Urban Midwest, 1860-1930. Columbus, OH: The Ohio State University Press.

Boaduo, N. A.-P. (2014). Undeniable Complacency of Western World Anthropology Scholars Ignorance in Acknowledging the Equality of Human Races: Revisiting Anténor Firmin in the New Millennium. Journal of Pan African Studies, 7, 34-44.

Bobo, L. D., Charles, C. Z., Krysan, M., \& Simmons, A. D. (2012). The Real Record on Racial Attitudes. In P. V. Marsden (Ed.), Social Trends in the United States: Evidence from the General Social Survey since 1972 (pp. 38-83). Princeton, NJ: Princeton University Press.

Brace, P., Butler, K. S., Arceneaux, K., \& Johnson, M. (2002). Public Opinion in the American States: New Perspectives Using National Survey Data. American Journal of Political Science, 46, 173-189. http://dx.doi.org/10.2307/3088421

Brown, S. M. (2014). Howard Ranks among Top HBCUs. Washington Informer, 49, 28-29.

Brown University: Department of Education (2014). Fall. http://www.brown.edu/academics/education/about/people

Cantey, N. I., Bland, R., Mack, L. R., \& Joy-Davis, D. (2013). Historically Black Colleges and Universities: Sustaining a Culture of Excellence in the Twenty-First Century. Journal of African American History, 17, 142-153. http://dx.doi.org/10.1007/s12111-011-9191-0

Carson III, L. C. (2013). Employment Opportunities and Conditions for the African-American Legal Professoriate: Perspectives from the Inside. Texas Journal on Civil Liberties \& Civil Rights, 19, 1-108.

Clement, A. J., \& Lidsky, A. J. (2011). The Danger of History Slipping Away: The Heritage Campus and HBCUs. Planning for Higher Education, 39, 149-158.

Chrisman, R. (2013). Black Studies, the Talented Tenth, and the Organic Intellectual. The Black Scholar, 43, 64-70. http://dx.doi.org/10.5816/blackscholar.43.3.0064

Copeland, L. (2011). July 1. For Blacks, a Return to Southern Roots. USA Today, p. 1A.

Cottman, M. H. (2014). Hard Times for Black Colleges. Ebony, 69, 36.

Countries and Areas Ranked by Population: 2013 (2014). US Census Bureau.

http://quickfacts.census.gov/qfd/states/48000.html

Dartmouth College: Department of Education (2014). Fall. http://www.dartmouth.edu/ educ/people/index.html

Decker, K. S. (2011). Perspectives and Ideologies: A Pragmatic use for Recognition Theory. Philosophy and Social Criticism, 38, 215-226. http://dx.doi.org/10.1177/0191453711427260

Distinguished University Professorships (2014). http://www.rackham.umich.edu/faculty-staff/awards/faculty-awards/distinguished-university-professorships.

Endowed Chairs and Endowed Professorships (2014). Michigan State University. http://cvm.msu.edu/research/endowed-chairs.

Evans, S. Y. (2007). Women of Color in American Higher Education. Thought \& Action, 23, 131-138.

Evans, G. L., \& Cokley, K. O. (2008). African American Women and the Academy: Using Career Mentoring to Increase Research Productivity. Training and Education in Professional Psychology, 2, 50-57. http://dx.doi.org/10.1037/1931-3918.2.1.50

Franklin, J. H. (1990). W.E.B. Du Bois: A Personal Memoir. The Massachusetts Review, 31, 409-428

Frazer, K. N. (2011). Academic Bullying: A Barrier to Tenure and Promotion for African-American Faculty. Florida Journal of Educational Administration \& Policy, 5, 1-13. 
Frey, W. H. (2011). A Pivotal Decade for America's White and Minority Populations. Brookings Institution. Series: State of Metropolitan America. http://www.brookings.edu/research/opinions/2011/03/25-census-demographics-frey.

Fryer, R., \& Greenstone, M. (2010). The Causes and Consequences of Attending Historically Black Colleges and Universities. American Economic Journal: Applied Economics, 2, 116-148. http://dx.doi.org/10.1257/app.2.1.116

Furedi, F. (2012). '”On Tolerance'. Policy: A Journal of Public Policy and Ideas, 28, 30-37.

Gardner, S. K., \&Blackstone, A. (2013). "Putting in Your Time": Faculty Experiences in the Process of Promotion to Professor. Innovative Higher Education, 38, 411-425. http://dx.doi.org/10.1007/s10755-012-9252-x

Gasman, M. (2010). Five Lessons for Campus Leaders: Academic Freedom, Shared Governance, and Tenure at an Historically Black University. Change: The Magazine of Higher Learning, 42, 54-57. http://dx.doi.org/10.1080/00091383.2010.523411

Gates, Jr., H. L. (2009). John Hope, the Prince Who Refused the Kingdom. The Root. http://www.theroot.com/print/8780

Griffin, R. A. (2012). In the Salon: Black Female Faculty “Talking Back” to the Academy. Women \& Language, 35, 75-79.

Griffin, K. L. (2013). Pursuing Tenure and Promotion in the Academy: A Librarian's Cautionary Tale. Negro Educational Review, 64, 77-96.

Harley, D. A. (2008). Maids of the Academy: African American Women Faculty at Predominantly White Institutions. Journal of African American Studies, 12, 19-36. http://dx.doi.org/10.1007/s12111-007-9030-5

Hartlep, N. D. (2014). A Model Minority? A National Look at Asian-Americans and Endowed Professors of Education. Diverse: Issues in Higher Education. http://diverseeducation.com/article/63996/

Hartlep, N. D., \& Theodosopoulos, K. (2014). African Americans Who Hold Endowed and Distinguished Professorships in Education. Journal of Blacks in Higher Education. http://www.jbhe.com/2014/10/african-americans-who-hold-endowed-and-distinguished-professorships-in-education/

Hill, R. F. (2011). Still Digitally Divided: An Assessment of Historically Black College and University Web Sites. Journal of Academic Librarianship, 38, 6-12. http://dx.doi.org/10.1016/j.acalib.2011.11.002

Hobbs, F., \& Stoops, N. (2002). Demographic Trends in the 20th Century. United States Census Bureau. CENSR-4. http://www.census.gov/prod/2002pubs/censr-4.pdf

Henshaw, A. L. (2014). Geographies of Tolerance: Human Development, Heteronormativity, and Religion. Sexuality and Culture, 18, 959-976. http://dx.doi.org/10.1007/s12119-014-9231-8

Irvine, J. J., \& Fenwick, L. T. (2011). Teachers and Teaching for the New Millennium: The Role of HBCUs. The Journal of Negro Education, 80, 197-208.

Johnson, M. N. (2013). Financial and Related Issues among Historically Black Colleges and Universities. Journal of Intercollegiate Sport, 6, 65-75.

Jones, T. B., \& Osborne-Lampkin, L. (2013). Black Female Faculty Success and Early Career Professional Development. Negro Education Review, 64, 59-75.

Jones, W. A. (2013). Prestige among Black Colleges: Examining the Predictors of HBCU Peer Academic Reputation. Journal of African American History, 17, 129-141. http://dx.doi.org/10.1007/s12111-012-9231-4

Kaba, A. J. (2008). Culture, Economic Progress and Immigration: The Hispanic/Latino Population in the US and the North African/Muslim Population in European Countries. The Delaware Review of Latin American Studies, 9, 1-11.

Kaba, A. J. (2009). Demographics and Profile: The Most Cited Black Scholars in the Social Sciences, Arts and Humanities. Journal of Pan African Studies, 3, 153-207.

Kaba, A. J. (2011). Demographics and Publication Productivity of Ivy League Political Science Professors: Harvard, Princeton, University of Pennsylvania and Yale. (3 Pages Double Space). Holler Africa Magazine.

http://www.hollerafrica.com/index.php

Kaba, A. J. (2012a). Black Americans and Interracial Marriage: A Focus on Black Women. Sociology Mind, 2, 407-427. http://dx.doi.org/10.4236/sm.2012.24054

Kaba, A. J. (2012b). Analyzing the Anglo-American hegemony in the Times Higher Education Rankings. Education Policy Analysis Archives, 20, 1-53. http://dx.doi.org/10.14507/epaa.v20n21.2012

Kaba, A. J. (2012c). Talented Tenth: An Analysis of the 2011 Root Magazine’s 100 Most Influential Young Black Americans. International Journal of Humanities and Social Science, 2, 1-31.

Kaba, A. J. (2013a). Profile of Contributors to the American Political Science Review, 2010. Journal of Politics and Law, 6, 54-82. http://dx.doi.org/10.5539/jpl.v6n2p54

Kaba, A. J. (2013b). Black Americans, Gains in Science and Engineering Degrees, and Gender. Sociology Mind, $3,67-82$. http://dx.doi.org/10.4236/sm.2013.31012 
Kaba, A. J. (2013c). The Exclusion of Black Women from National Leadership Positions in the United States: Taxation with Limited Representation. Sociology Mind, 2, 133-140. http://dx.doi.org/10.4236/sm.2012.22017

Kaba, A. J. (2014) A Statistical Report on the Educational Attainment Status of Black Americans. African Renaissance, 11, 79-100.

Keating, A. D. (2014). Keep up the Agitation. Rev. Jerry Forshey and a KKK Cross from Jackson, Mississippi. Journal of the Illinois Historical Society, 107, 45-76. http://dx.doi.org/10.5406/jillistathistsoc.107.1.0045

Lawrence-Lightfoot, S. (1999). Respect. An Exploration. Cambridge, MA: Perseus.

Lee, T. E. (2010). Tolerance as a Concept: Paradoxical or Practicable? Forum on Public Policy: A Journal of the Oxford Round, 2010, 1-10.

Lemelle Jr., A. J. (2010). Social and Economic Organization of the Black Professoriate at Predominately-White Colleges and Universities. Journal of African American Studies, 14, 106-127. http://dx.doi.org/10.1007/s12111-009-9115-4

Lesesne, C., \& Stuart, R. (2013). Remaining Relevant: Future of Black colleges Hinges on Evolving with the Times. Diverse: Issues in Higher Education, 30, 8-9

López, M. P., \& Johnson, K. R. (2014). Presumed Incompetent: Important Lessons for University Leaders on the Professional Lives of Women Faculty of Color. Berkeley Journal of Gender and Law, 29, 388-405.

Merda, C. (2014). Martin Luther King, Jr. and His Time in Chicago. Chicago Sun-Times. Voices. http://voices.suntimes.com/news/mulitmedia/martin-luther-king-jr-and-his-time-in-chicago/

Moore, H. K., \& Walker, A. (2011). Tolerance: A Concept Analysis. Journal of Theory Construction \& Testing, 15 , 48-52.

Mondak, J., \& Sanders, M. S. (2003). Tolerance and Intolerance, 1976-1998. American Journal of Political Science, 47, 492502. http://dx.doi.org/10.1111/1540-5907.00035

News and Views: A JBHE Report Card on the Progress of Blacks on the Faculties of the Nation's Highest-Ranked Colleges and Universities (2002). Journal of Blacks in Higher Education, 34, 10-12.

Nichols, J. C. (2004). Unique Characteristics, Leadership Styles, and Management of Historically Black Colleges and Universities. Innovative Higher Education, 28, 219-229. http://dx.doi.org/10.1023/B:IHIE.0000015109.49156.fb

Oplatka, I. (2010). The Professoriate in the Field of Educational Administration. Journal of Educational Administration, 48, 392-412. http://dx.doi.org/10.1108/09578231011041071

Nealy, M. J. (2009). Pride and Peril: Historically Black Colleges and Universities. Diverse: Issues in Higher Education, 26, 18-19.

Nieto, S. (1994). Affirmation, Solidarity, and Critique: Moving beyond Tolerance in Multicultural Education. Multicultural Education, 1, 9-12, 35-38.

Palmer, R. T., \& Griffin, K. A. (2009). Desegregation Policy and Disparities in Faculty Salary and Workload: Maryland’s Historically Black and Predominately White Institutions. The Negro Educational Review, 60, 7-21.

President Napolitano Announces Matching Fund to Create 100 New Endowed Chairs at UC (2016). UC Office of the President. University of California System.

http://www.universityofcalifornia.edu/press-room/president-napolitano-announces-matching-fund-create-100-new-endowe d-chairs-uc.

Price, G. N. (2008). NEA Presidential Address: Black Economists of the World You Cite! The Review of Black Political Economy, 35, 1-12. http://dx.doi.org/10.1007/s12114-008-9009-z

Ralph Jr., J. R. (1993). Northern Protest: Martin Luther King, Jr., Chicago, and the Civil Rights Movement. Cambridge, MA: Harvard University Press.

Rastogi, S., Johnson, T. D., Hoeffel, E., \& Drewery Jr., M. (2011). The Black Population: 2010. US Census Bureau. C2010BR06. http://www.census.gov/prod/cen2010/briefs/c2010br-06.pdf

Robertson, T. (2002). Harvard Exodus. New Crisis, 109, 22-27.

Samson, F. L., \& Bobo, L. D. (2014). Ethno-Racial Attitudes and Social Inequality. In J. McCleod, E. Lawler, \& M. Schwalbe (Eds.), Handbook of the Social Psychology of Inequality (pp. 515-546). New York: Springer. http://dx.doi.org/10.1007/978-94-017-9002-4_21

Saulius, T. (2013). What Is “Tolerance” and “Tolerance Education”? Philosophical Perspectives. Education. Physical Training, 89, 49-55.

Schirmer, W., Weidenstedt, L., \& Reich, W. (2012). From Tolerance to Respect in Inter-Ethnic Contexts. Journal of Ethnic and Migration Studies, 38, 1049-1065. http://dx.doi.org/10.1080/1369183X.2012.681448

Selected Population of the United States 2011 American Community Survey 1-Year Estimates (2013). American Fact Finder. United States Census Bureau. http://factfinder2.census.gov/faces/tableservices/jsf/pages/productview.xhtml?src=bkmk 
Shaw, R. E. (2001). A Final Push for National Legislation: The Chicago Freedom Movement. Journal of the Illinois State Historical Society, 94, 304-332.

Stone, C. (2001). A Roster of African Americans Who Hold Endowed University Chairs. Journal of Blacks in Higher Education, 33, 121-125. http://dx.doi.org/10.2307/2678940

Stern, G. M. (2005). Ivy League Colleges Not Hiring Tenure-Track Minorities. The Hispanic Outlook in Higher Education, $15,19-23$.

SUNY Board of Trustees Appoints 19 Faculty to Distinguished Ranks (2014). State University of New York. http://www.suny.edu/suny-news/press-releases/may-2014/5-14-14-distinguished/suny-board-of-trustees-appoints-19-facult y-to-distinguished-ranks.html

Table 315.20. Full-Time Instructional Faculty in Degree-Granting Postsecondary Institutions, by Race/Ethnicity, Sex, and Academic Rank: Fall 2007, Fall 2009, and Fall 2011 (2014). National Center for Education Statistics. US Department of Education. http://nces.ed.gov/programs/digest/d13/tables/dt13_315.20.asp

Table 705. Money Income of People-Number by Income Level and by Sex, Race, and Hispanic Origin: 2009 (2012). Statistical Abstract of the United States. United States Census Bureau. http://www.census.gov/compendia/statab/2012/tables/12s0705.pdf

Taylor Jr., J. C. (2012). A Call to Accountability: The HBCU Board. Diverse: Issues in Higher Education, $29,31-32$.

Thomas, B. (2010). Under the Guise of Self: Racial Identity, Self-Respect, and Recognition. Philosophia Africana, 13 , 1-21. http://dx.doi.org/10.5840/philafricana20101316

Toch, T., \& Burke, S. (1993). Inside the Ivy League. US News and World Report, 114, 55-60.

Unz, R. (2012). The Myth of American Meritocracy. American Conservative, 11, 14-51.

Vander Velde, L. (2011). The Dred Scott Case as an American Family Saga. OAH Magazine of History, $25,24-28$. http://dx.doi.org/10.1093/oahmag/oar010

Von Bergen, C. W., Von Bergen, B. A., Stubblefield, C., \& Bandow, D. (2012). Authentic Tolerance: Between Forbearance and Acceptance. Journal of Cultural Diversity, 19, 111-117.

Wagner, G. (2011). The Two Sides of Recognition: Gender Justice and the Pluralization of Social Esteem. Critical Horizon: A Journal of Philosophy \& Social Theory, 12, 347-371.

Warde, B. (2009). The Road to Tenure: Narratives of African American Male Tenured Professors. Journal of African American Studies, 13, 494-508. http://dx.doi.org/10.1007/s12111-008-9061-6

What Is a Distinguished Professor? (2014). City University of New York. http://www.cuny.edu/about/alumni-students-faculty/faculty/dp/faqs.html

Wilder, C. S. (2013). Ebony \& Ivy: Race, Slavery, and the Troubled History of America's Universities. New York: Bloomsbury.

Yovel, Y. (1998). Tolerance as Grace and as Rightful Recognition. Social Research, 65, 897-919. 


\section{Appendix A}

\section{Regional Breakdown of the United States ( $\mathrm{N}=51$ )}

\section{Northeast $(\mathbf{n}=9)$}

Connecticut, Maine, Massachusetts, New Hampshire, New Jersey, New York, Pennsylvania, Rhode Island, Vermont.

Midwest $(\mathbf{n}=12)$

Illinois, Indiana, Iowa, Kansas, Michigan, Minnesota, Missouri, Nebraska, North, Dakota, Ohio, South Dakota, Wisconsin.

South $(\mathbf{n}=\mathbf{1 7})$

Alabama, Arkansas, Delaware, District of Columbia, Florida, Georgia, Kentucky, Louisiana, Maryland, Mississippi, North Carolina, Oklahoma, South Carolina, Tennessee, Texas, Virginia, West Virginia.

West (n = 13)

Alaska, Arizona, California, Colorado, Hawaii, Idaho, Montana, Nevada, New Mexico, Oregon, Utah, Washington, Wyoming.

Source: "Summary Social, Economic, and Housing Characteristics: 2000 Census of Population and Housing," (2003, June). Selected Appendixes: 2000. PHC-2-A. Washington DC: US Census Bureau. 